Status Report 2016-2019

\title{
Paleoseismological Studies in India (2016-2020): Status and Prospects
}

C P RAJENDRAN ${ }^{1, *}$, TEJPAL SINGH ${ }^{2}$, MALAY MUKUL ${ }^{3}$, MAHESH THAKKAR $^{4}$, GIRISH CH KOTHYARI $^{5}$, BIJU JOHN ${ }^{6}$ and K RAJENDRAN ${ }^{7}$

${ }^{1}$ Geodynamics Unit, Jawaharlal Nehru Centre for Advanced Scientific Research, Jakkur, Bengaluru 560064 , India

${ }^{2}$ CSIR-Central Scientific Instruments Organisation, Sector 30C, Chandigarh 160 030, India

${ }^{3}$ Department of Earth Sciences, Indian Institute of Technology, Mumbai, India

${ }^{4}$ Department of Earth and Environmental Science, K.S.K.V. Kachchh University, Bhuj, Kachchh 370

001, India

${ }^{5}$ Institute of Seismological Research, Gandhinagar, Gujarat 382 007, India

${ }^{6}$ Seismotectonics Unit,National Institute of Rock Mechanics, Bengaluru 560 070, India

${ }^{7}$ Centre for Earth Sciences, Indian Institute of Science, Bengaluru 560 012, India

(Received on 01 September 2019; Accepted on 29 September 2019)

\begin{abstract}
The last few years have witnessed consistent growth in paleoseismic investigations and active fault research in India. An overview of relevant publications during 2016-2020 indicates that this field is now widely accepted as a tool to characterize the seismic hazard in the country. Such studies initiated in the country in early nineties have gained momentum and widened its scope into a variety of tectonic and morphological settings. While earthquake frequency and fault activations are major objectives of such studies, the Indian researchers are now equally interested in constraining the fault geometry and the nature of near-surface crustal deformation, thereby contributing to earthquake hazard evaluations. This has been driven by an ever-increasing interaction between experts from associated fields like geomorphology, neotectonics, seismology, geodesy, modeling etc. Future challenges would include integrating the paleoseismological observations with the relevant geophysical inputs to develop physical models of the earthquake cycles, ultimately leading to an inventory of the active faults. Although there are gaps and disagreements on how things operated at different spatial and temporal scales, there have been broad agreements in general. The future should focus on evolving new strategies and methodologies to integrate different datasets in a coherent manner to yield practically relevant results and models that can explain data from various spatial and temporal scales.
\end{abstract}

Keywords: Active Fault; Earthquakes; Liquefaction; Neotectonics; Paleoseismology

\section{Introduction}

The northward progression of the Indian plate at a current rate $\sim 50 \mathrm{~mm} / \mathrm{yr}$ produces tectonic strains across the Indian sub-continent, resulting in frequent earthquakes of varying magnitudes mostly along the plate boundary region (Fig. 1). The Indian subcontinent has a not-so-well documented history of earthquakes that is, of course, also poorly understood. However, with the advancement of technology, the last few decades have seen a considerable progress in monitoring of current seismicity as well as

*Author for Correspondence: E-mail: cprajendran@gmail.com documenting the near-surface manifestations of past large earthquakes and consequent deformation expressed by the geology and geomorphology (Rajendran, K et al., 2017; references therein). It has also been a challenge to carry out research on past earthquakes as their ground level manifestations are subjected to surface processes and often tend to fade away or even vanish with time. Nevertheless, much of the scientific research to understand past earthquakes has primarily focused on the identification, mapping and dating of tectonic landforms such as uplifted or offset terraces, fault-line scarps, fault scarps 


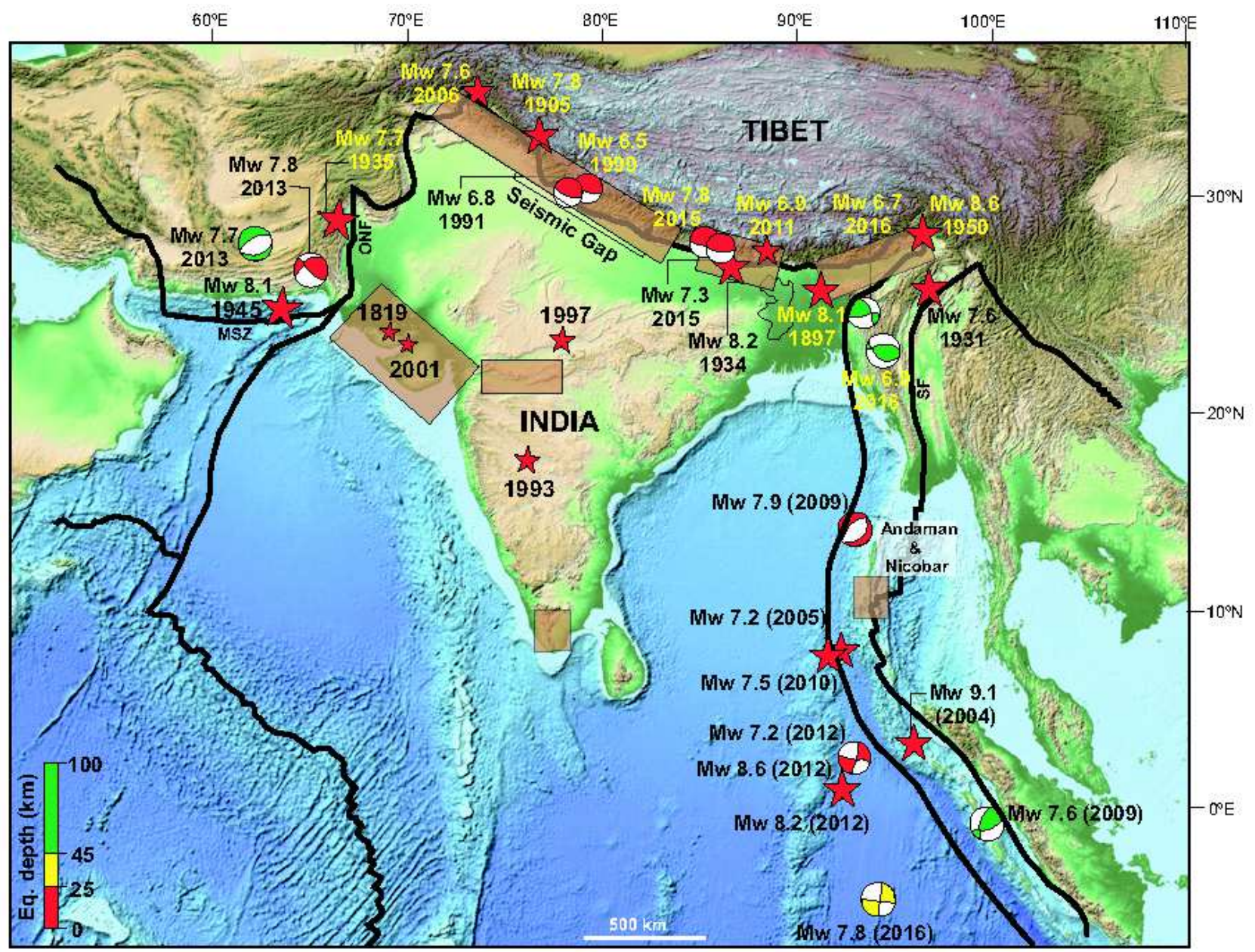

Fig. 1: Map of India including Andaman and Nicobar Islands showing distribution of major earthquakes. Shaded boxes indicate the study areas during the reporting period (2016-2020)

and an active fault itself. The complete exercise is dedicated to making qualitative and quantitative assessment of surface rupturing earthquakes using geomorphic proxies. Also, depending on the type and character of landforms employed for the studies, the specificity of surface deformation could be ascertained. The fluvial/marine terraces overlying active faults can help to identify long-term deformation rates over thousands to millions of years whereas the fault offsets preserved in the geological sections themselves can help to constrain short-term deformation rates over seismic cycles of decades to centuries or much beyond. The sediment trapped along active fault traces can provide means to pin down the timing of the seismic activity of the past, although with a degree of uncertainty inherent in the geochronological techniques. Besides the exposures of the fault-related displacements, indirect earthquake proxies like liquefaction-related features and growth perturbations of stalagmites within limestone caves have also been subjects of enquiry.

There has been noticeable progress in active fault research in India over the last decade. Seeing the urgent need for seismic hazard assessment, the Ministry of Earth Sciences pro-actively engaged experts who conceived the "Active Fault Mapping Program" and brought out a booklet on Standard Operating Procedures (SOPs). The most vulnerable zones, as per the seismic zonation map of India, have been prioritized. The current major initiatives in active fault mapping are focused in the Western to eastern Himalaya and Gujarat regions (Fig. 1). Besides such programs, there have been many other individual and team efforts from India and abroad during the reporting period (2016-2020). In the following sections, we will be evaluating the paleoseismological work 
conducted during 2016 to 2020 for which we have used the published papers, reports and books. We may also occasionally refer to some relevant publications before 2016 only ifthey are found to be useful to build a context while discussing the work during 2016 to 2020.

\section{The Himalaya}

The Himalayan domain, one of the most active and extremely complex tectonic settings is the one among the few regions where great surface-rupturing earthquakes have been reported (Fig. 2A). The Main Frontal Thrust (MFT), also known as the Himalayan Frontal Thrust (HFT) is the youngest and southernmost structure in the Himalayan fold-thrustbelt (Fig. 2B). Like the interior thrust systems, namely, the Main Boundary Thrust (MBT) and the Main Central Thrust (MCT) sole into a regional décollement, named as the Main Himalayan Thrust (MHT) that forms the contact between Indian and Asian plates (Fig. 2B). It is highly segmented along its strike and each of the segments are characterized by different seismo-tectonic features. However, it is observed that much of the large surface rupturing earthquakes have cut-across such segmentation and evidence has been reported over large distances (see Bilham, 2019; references therein). Another point to be reckoned with is that the décollement may also have shallower ramps up-dip like the deeper one beneath the High Himalaya that act as geometric barriers to earthquake propagation (Hubbard et al., 2016; Almeida et al., 2018; Bai et al., 2019). The last decade has witnessed a vigorous seismological research in the Himalayas. The paleoseismological work reported from the northwestern Himalaya (including Kashmir) to central and eastern Himalaya has provided valuable information on the spatial and temporal distribution of the past Himalaya earthquakes.

\section{Kashmir Himalaya}

The Kashmir Himalaya has been one of the most vulnerable areas in terms of its surface topography and geo-political situation, and any plans on disaster preparedness will have to include these two factors into consideration. Historically two earthquakes stand out, namely the 30 May 1885 (Mw 6.3) and the 1555 (Mw 7.6), which mostly damaged the northern parts of the Kashmir Valley including the capital city of Srinagar, Sopore, Baramulla and Pattan (Sana et al.,
2018; Fig. 3). The 1885 earthquake is reported to have caused 3400 causalities and damaged prominent buildings including the twin temples of Pattan. An earlier generation of damage attributed to the 1555 earthquake has also been reported (Sana et al., 2018). Despite the low magnitude of the 1885 earthquake, the unusual rain extending to the end of May of 1885 may have contributed to the triggering of landslides and even soil liquefaction, mostly reported from the village of Laridora in the district of Baramulla (Sana and Nath, 2016). These findings suggest that both the 1885 and the 1555 earthquakes may have been generated on a hinterland structure closer to the Kashmir basin.

The 2005 Kashmir earthquake (Mw 7.6), occurred on an out-of-sequence structure oriented somewhat tangential to the MBT. It was the most important event to have happened in Kashmir since the 1885 earthquake that pushed the boundaries of active fault research into this difficult terrain. The follow-up investigations of the 2005 surface rupture led to several hypotheses suggesting its continuation into the Kashmir Valley. Various interpretations indicate the overlapping of different deformation regimes that could have been most likely caused by the structural heterogeneity within the Kashmir basin (Alam et al., 2017; Dubey et al., 2017). Contrary to the overall compression in the Himalaya, Alam et al. (2017) suggest dominantly extensional tectonics in the valley. The geomorphology also suggests an accompanied out-of-sequence reverse faulting along the Balapur Fault (BF) within the Kashmir basin wherein the co-existent compressional features in an extensional setting lend a hybrid character (coexistence of both compressional and extensional features) to this basin (Alam et al. 2017).

These observations of active tectonic deformation have been further complemented by the identification of a few more active faults from Kashmir Himalaya (Shah and Malik 2017). Based on their interpretations of geomorphic features (e.g. deformed fluvial terraces), Ahmad et al. (2017), suggest that the southwest Kashmir is tectonically active. The recent activity of the Medlicott-Wadia Thrust (MWT) is investigated in the Riasi zone where the MWT forms a splay of five faults dipping north (Mugnier et al., 2017). It is suggested that nearly $10 \mathrm{~mm} / \mathrm{yr}$ of India-Eurasia convergence is regularly 


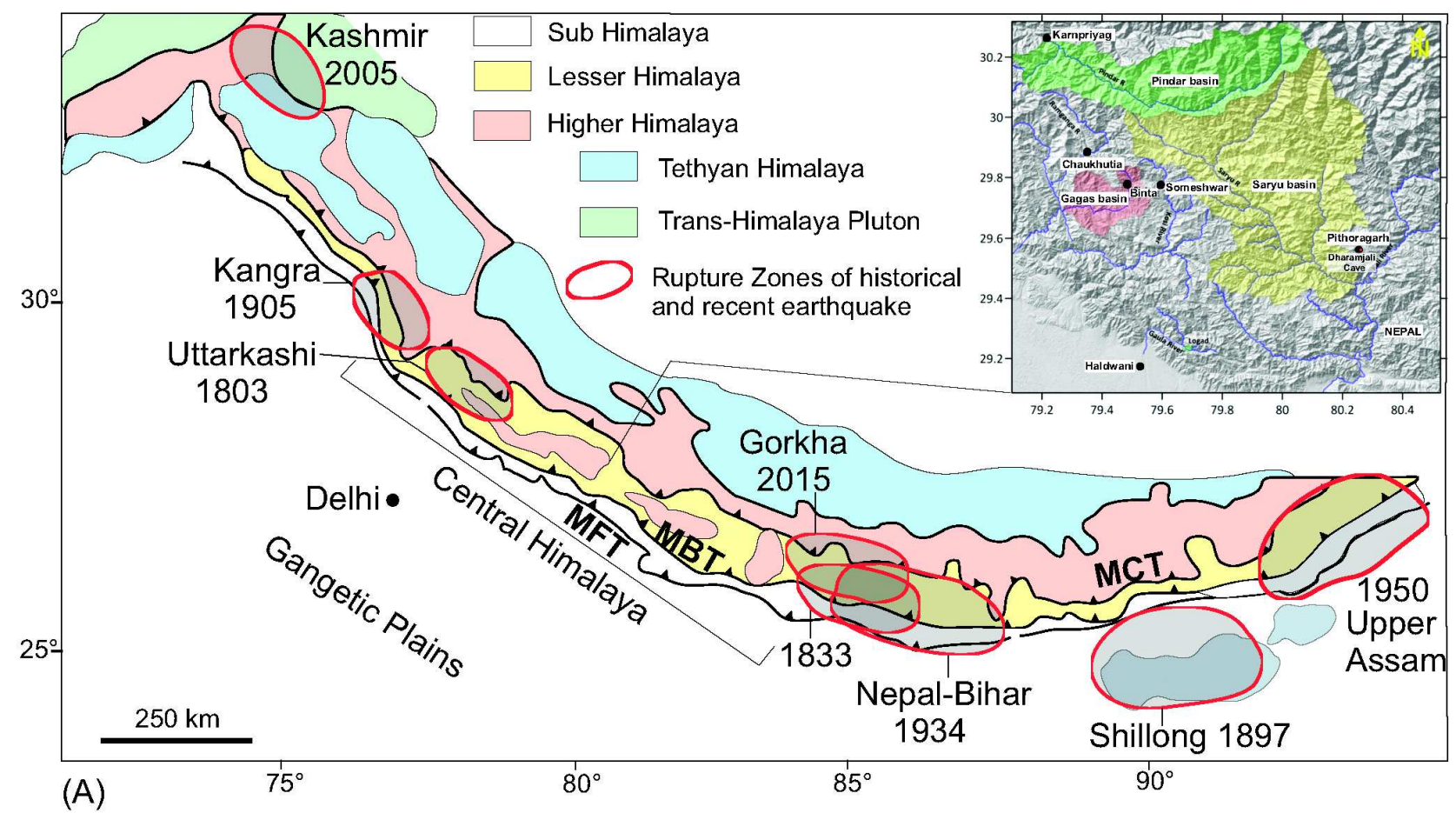

(A)

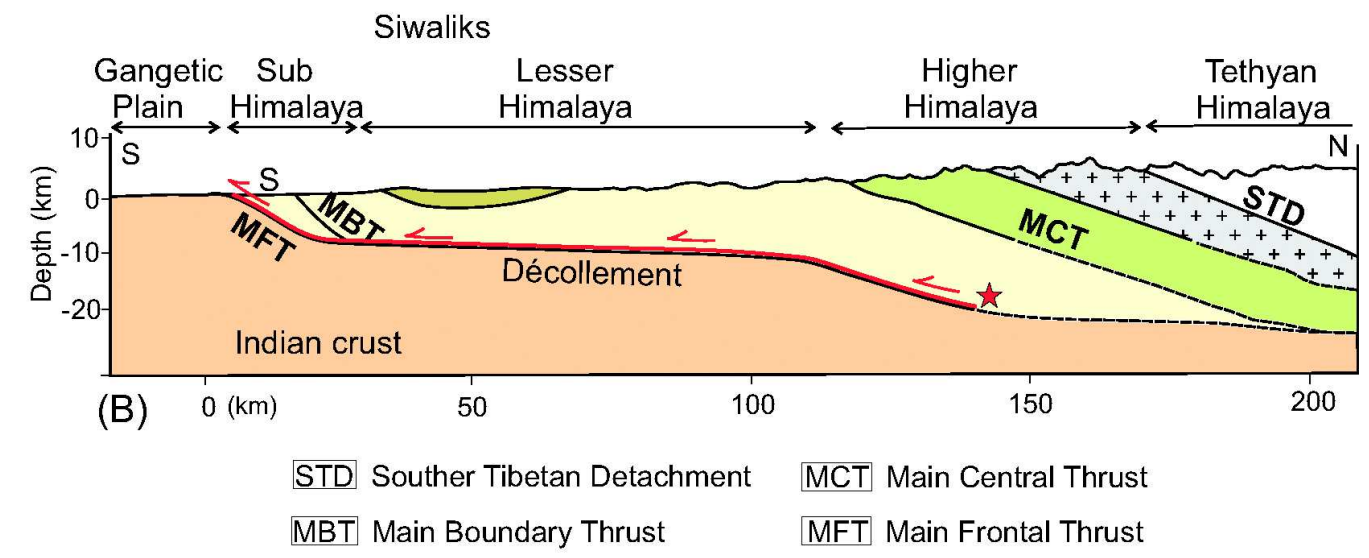

Fig. 2: A. Map showing tectonic domains and major thrusts of the Himalaya: (MCT: Main Central Thrust, MBT: Main Boundary Thrust and MFT: Main Frontal Thrust). Rupture zones of major historical and recent earthquakes are also shown. Inset: Map showing the locations of Pindar and Sarayu basins within the Kumaun Himalaya. B. Generalized section across the central Himalaya showing the geometry of various thrust systems, which sole into a décollement (the Main Himalayan Thrust: MHT). The great earthquakes sourced at the base of the ramp-flat system propagate slip southward along the décollement (the zone of earthquake nucleation not precisely located) activate the Himalayan front along the MFT. The recent earthquake like the 2005 Kashmir, however, underscores the role of hinterland thrusts in hosting the earthquakes

absorbed by the MWT, which is anomalous and might be related to thick-skinned tectonics in the western Himalaya.

\section{NW Himalaya}

In its early years the paleoseismological/active fault research in the NW Himalaya region (Fig. 3) was concentrated much along the Himalayan Frontal Thrust zone with literally no work reported from the hinterland. Notwithstanding the importance of the frontal zone to understand the deformation associated with the foreland-ward slip transfer along the basal décollement during great earthquakes (Srivastava et al., 2016, 2018), the hinterland areas must also be 


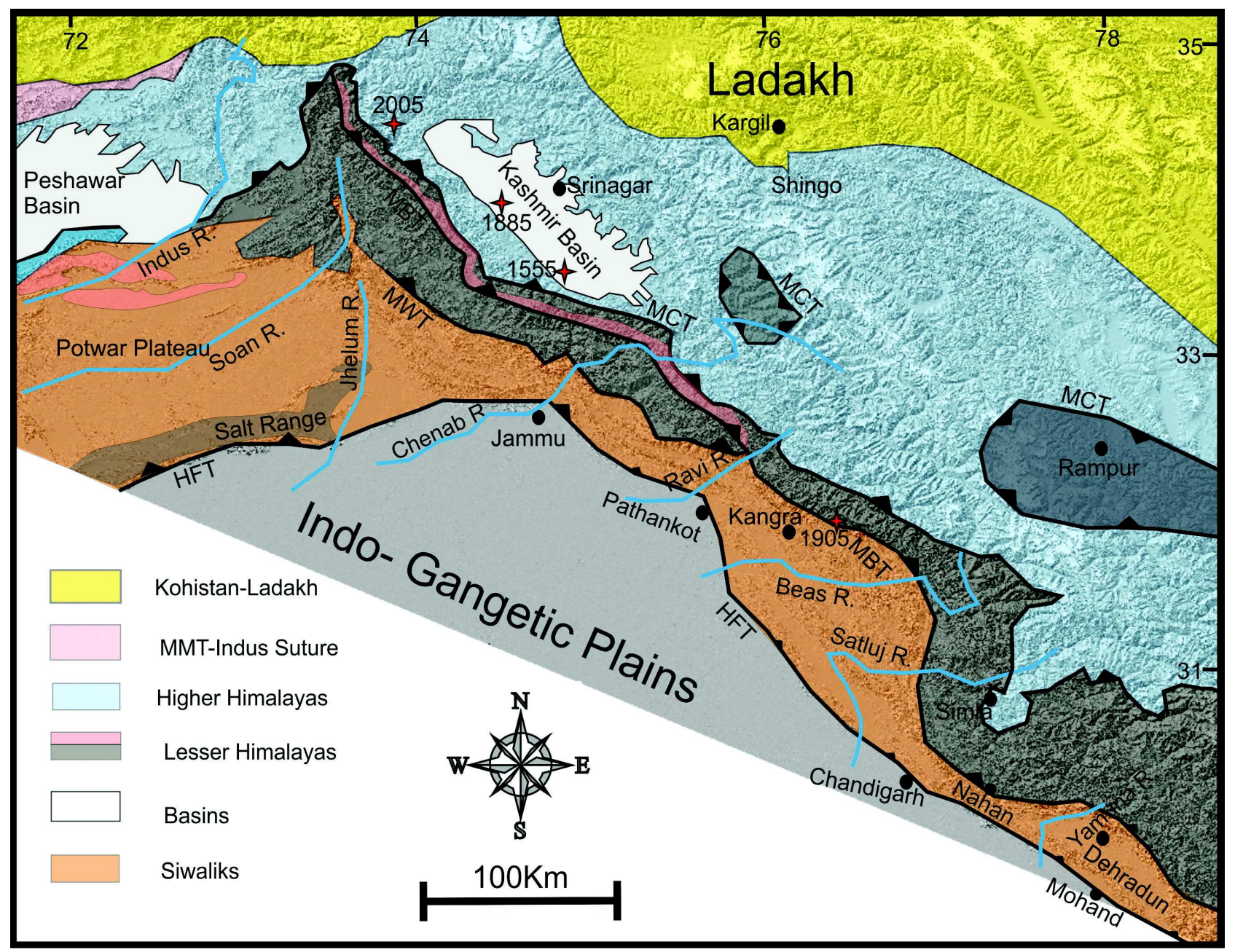

Fig. 3: Surface topography and geology of the northwest Himalaya and major litho-tectonic units, structural domains and boundaries. The stars represent major earthquakes (with year). Locations of the 1885 (Mw $\sim 6.3)$ and 1555 (Mw 7.6) earthquakes are after Sana et al. (2018). MCT-Main Central Thrust; MBT-Main Boundary Thrust; MWT-MedllicottWadia Thrust; HFT-Himalayan Frontal Thrust

considered for active fault research and paleoseismology as the MFT might not have ruptured during all past earthquakes (e.g. Dey et al., 2016; Jayangondaperumal et al., 2017a). This was particularly noteworthy in the background of the recently acquired data on the active nature of the Jwalamukhi Thrust (JT) in the Kangra area (Dey et al., 2016). Subsequently, it has been demonstrated that the structure of the Fold-Thrust-Belt (FTB) is largely controlled by the geometry of the underlying basement and the overlying lithologies (Singh et al., 2012).

Complementing some of the earlier studies, Arora et al. (2019) presented data on coseismic slip and timing of the youngest faulting along the Pinjore
Garden Fault (PGF) and Jhajra Fault (JF) in the Pinjore Dun. Trench investigations along these spatially small faults suggest at least two earthquakes, one of which occurred after $1283 \mathrm{CE}-1443 \mathrm{CE}$ and the other around $1223 \mathrm{CE}-1442 \mathrm{CE}$. They reported that these hinterland faults might have been reactivated by an independent earthquake event between $1283 \mathrm{CE}$ and $1600 \mathrm{CE}$ which could not reach the mountain front. The results also suggest that there have been multiple large magnitude earthquakes between $1200 \mathrm{CE}-1600 \mathrm{CE}$.

A compilation of some ongoing research was published during the reporting period as a special volume of the journal Quaternary International (Jayangondaperumal et al., 2017b). The volume presents 16 topical papers, which include 
morphotectonic analyses from the Nahansalient using several geomorphic indices such as stream length gradient index (steepness index), Hack profile convexities, and hypsometric integral (HI) alongwith hypsometric curve and elevation profiles (Kaushal et al., 2017). These studies reported spatially variable tectonic process across the Nahansalient and also reported identification of new active structure(s) that could be important for an improved seismotectonic evaluation of the salient

Further west in the Kangra recess, Sahoo and Malik (2017) worked out further details of the active fault topography of the right lateral strike-slip fault i.e. the Kangra Valley Fault (KVF) along its length of about $60 \mathrm{~km}$. The stream offsets across the active $\mathrm{KVF}$ range from $10 \mathrm{~m}$ to $340 \mathrm{~m}$. The presence of the KVF between two major thrust systems i.e., the MBT and the JT, suggests that slip-partitioning is taking place between the thrust and strike-slip faults and the net mode of deformation is the result of oblique convergence in NW Himalaya. Based on the typical ' $\mathrm{Y}$ ' shaped pattern of the KVF, two possibilities for the surface rupture propagation are suggested: (1) the fault rupture initiated from the eastern side and propagated unilaterally towards west, and (2) taking into account the ' $\mathrm{Y}$ ' shape on both the end sections of the fault trace, it can be inferred that the rupture during most recent event probably started in the center and propagated bilaterally in an E-W direction.

Further work on fault related parameters, gradient-length anomaly (GLA) analysis, and Interferometric Synthetic Aperture Radar (In-SAR) measurements have been conducted by Kothyari et al. (2019a) to understand the landscape evolution and deformation pattern within the Soan dun area of northwest Himalayan front. The analysis of fault parameters suggests that the horizontal shortening of northwest Himalaya is higher than the vertical uplift. The combined results of GLA magnitude analysis and In-SAR shows that the depicted range of vertical deformation ranges from -3.13 to $+3.14 \mathrm{~mm} / \mathrm{yr}$, which appears to be consistent with chronologically constrained uplift rates of $3.4 \pm 0.3 \mathrm{~mm} / \mathrm{yr}$, reported by Thakur et al. (2014).

What is important to note here is that all these studies in the NW Himalaya bring out the importance of interior structures in generating the earthquakes.
Does it mean the ruptures of the MHT get accommodated within these structures rather than propagating to the MFT? Recent investigations of the seismotectonics of the Central and NW Himalaya suggest a difference in how convergence is accommodated in terms of thin- and thick-skin tectonic framework (Thakur et al., 2018). It is argued that this difference explains the occurrence of giant earthquakes in the central Himalaya and the lack of such events in the NW Himalaya.

\section{Garhwal and Kumaun Himalaya}

The timing and size of the last great earthquake in the central Himalaya continues to generate scientific debate, despite a decade of paleoseismological investigations (e.g. Rajendran et al., 2018a). The studies along the frontal thrust in the Indian part of the central Himalaya indicate a faulting event between $14^{\text {th }}$ and $15^{\text {th }}$ century (Fig. 4A). Jayangondaperumal et al. (2017a) reviewed a compilation of paleoseismic results from the Garhwal-Kumaun Himalaya across the Central Seismic Gap (CSG), including parts of the Nepal Himalaya. They suggest that the entire western half of the CSG could have ruptured in an earthquake event in $1344 \mathrm{CE}$ that corresponds well with the historical accounts of a medieval earthquake.

Lately, Rajendran et al. (2018b) evaluated the database along with independent inputs to determine the timing of the last faulting event on the frontal thrust of the central Himalaya. The newly geological data from multiple trenches across the frontal thrust (including the farwestern Nepal) show that the last faulting event occurred between $13^{\text {th }}$ and $14^{\text {th }}$ centuries - the time interval coinciding with the $1344 \mathrm{CE}$ earthquake (Fig. 4B). The episodic valley fills identified in the Pokhara Valley in the east-central Nepal provide additional constraints for the $1344 \mathrm{CE}$ earthquake along with two previous ones in 1255 and 1100 CE (Stolle et al., 2017). The consilience of multiple pieces of evidence from India and Nepal in combination with the new data inputs from two trench locales (Chorgalia near the India-Nepal border and Mohana Khola in Far-western Nepal) implicates the $1344 \mathrm{CE}$ as the last of the medieval sequence of earthquakes. With a rupture length of $\sim 600 \mathrm{~km}$ of the central Indian Himalaya, and an average slip of $15 \mathrm{~m}$ this earthquake is consistent with moment magnitude of $\mathrm{Mw} \geq 8.5$. An earthquake of similar size is overdue 

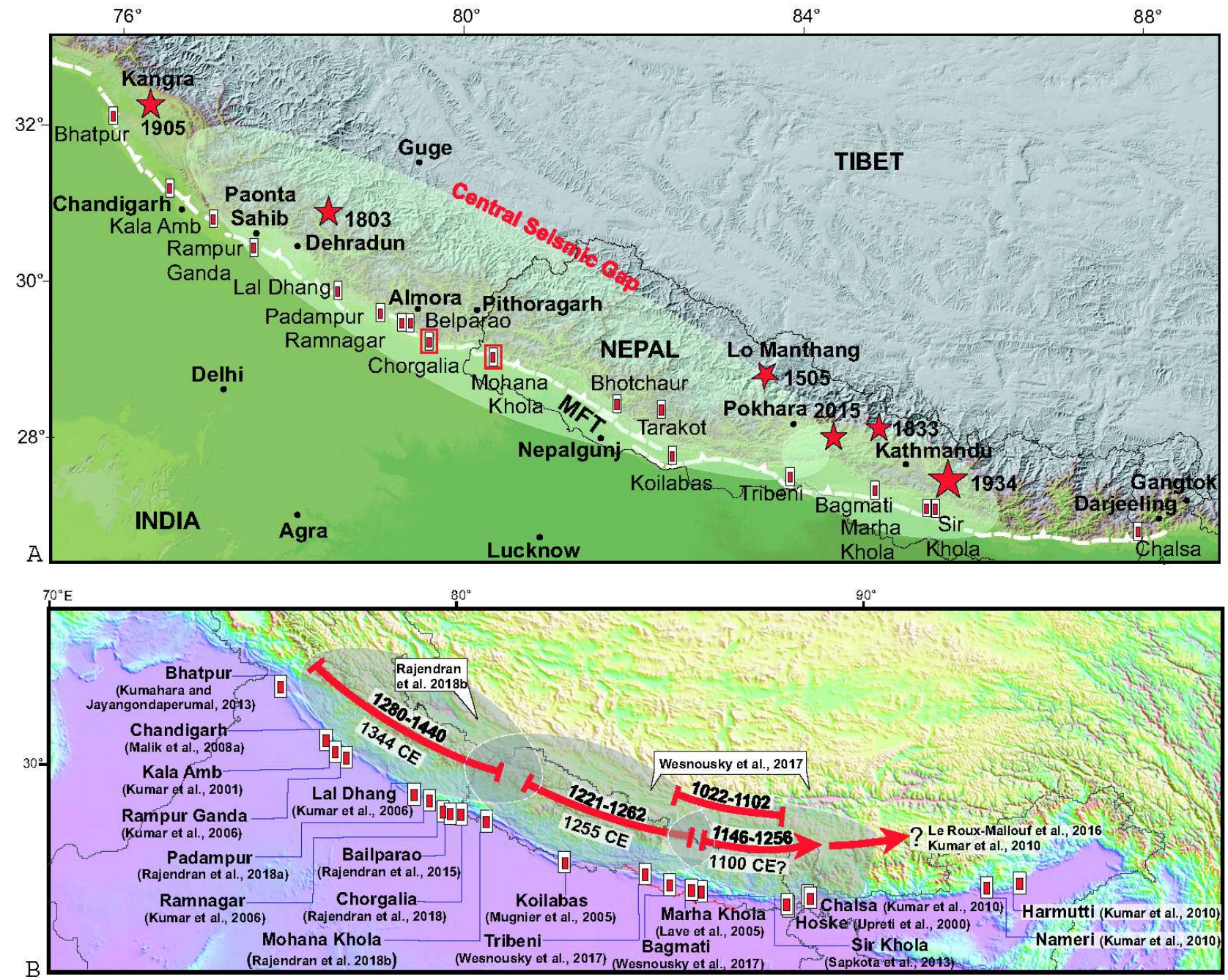

Fig. 4: A. Map showing central Himalaya seismic gap with source areas of major earthquakes (Mw $\geq 7.5$ ) (adopted from Rajendran et al., 2018b). Trench sites are marked by filled red rectangular boxes. B. Spatial extent of surface ruptures of medieval earthquakes along the central-eastern Himalaya: 1315-1440 CE (this study); 1221-1262 CE (Wesnousky et al., 2017) and 1146-1256 CE (Wesnousky et al., 2017). Corresponding candidate historical earthquakes of 1344 and 1255 CE that fall within the time brackets are also shown. Trench sites are marked by filled red rectangular boxes

in this part of the Himalaya, considering the longelapsed time of $\leq 700$ years.

In the Kumaun Lesser Himalaya, Taloor et al. (2017) and Kothyari et al. (2017a) carried out the tectono-geomorphic evaluation of the Binta basin (Fig. Fig. 2; inset). They suggested that the zone north of the active North Almora Thrust (NAT) is vulnerable for the future earthquakes. Another prominent NWSE trending linear feature named as the Logar fault, which reportedly displaced the Quaternary alluvial fan (Logar fan) was delineated previously at Logar Village in the northwestern Kumaun Sub-Himalaya byPhilip et al. (2017). Based on the surface expression of the discontinuous scarp, and its expression on the satellite data, the fault has been further extended on either side to a total length of $\sim 9.5 \mathrm{~km}$, which in part lies in the mega thrust zone along the MBT. Variable height of the fault scarp along its strike suggests multiple faulting events that occurred along the same fault. The OSL ages (on quartz) from the footwall show that multilevel surfaces deposited between 20 and $8.7 \mathrm{ka}$. However, in the hanging wall, the base of the vertically stacked deposits shows an age $\sim 20 \mathrm{ka}$. The OSL age in the bottom unit of the trench in the hanging wall suggests the commencement of post-faulting deposition of the units after $20 \mathrm{ka}$. In the footwall, 
younger ages of 11 and 8.7 ka probably represent the youngest activity on the fault.Furthermore, chronological constraints of the landforms (bedrock strath terraces) of Saryu and Pindar river basins (Fig. 2 ; inset) suggest tectonic activity between 3 to $45 \mathrm{ka}$ (Kothyari and Luirei, 2016; Kothyari et al., 2017b). Based on chronology of strath terraces preserved along the longitudinal length of the above-mentioned rivers, seven phases of bedrock uplift have been determined during $44 \mathrm{ka}(3.34 \mathrm{~mm} / \mathrm{yr}), 35 \mathrm{ka}$ $(1.84 \mathrm{~mm} / \mathrm{yr}), 15 \mathrm{ka}(0.91 \mathrm{~mm} / \mathrm{yr}), 14 \mathrm{ka}(0.83 \mathrm{~mm} /$ yr), $9 \mathrm{ka}(1.75 \mathrm{~mm} / \mathrm{yr}), 7 \mathrm{ka}(5.38 \mathrm{~mm} / \mathrm{yr})$, and around $3 \mathrm{ka}(4.4 \mathrm{~mm} / \mathrm{yr})$

A study of trench stratigraphy near the central (Indian) Himalayan foothills near Padampur by Malik et al. (2016) had reported multiple ruptures dated at 467-570, 1294-1587 and 1750-1932 CE (see Fig. 4A for location). The last offset has been attributed to the historical Uttarkashi earthquake of 1803 and the penultimate faulting, with lesser confidence, is ascribed to the 1505 earthquake. Paleoseismic investigations in an adjacent new trench section on a shared scarp by Rajendran et al. (2018b)did not find any supporting evidence for the previous interpretation of the trench stratigraphy by Malik et al. (2016) that suggested multiple displacements cutting across a varied set of deformed stratigraphic units leading up to the 1803 rupture. The latter interpretation posits a single episode of a low-angle displacement at this site possibly occurred between 1266 and $1636 \mathrm{CE}$ and disavows the claim that the 1803 earthquake ruptured the MFT.

The Geological Survey of India has conducted several investigations around the Yamuna Tear Fault (Fig. 3) in the frontal part (Joshi et al., 2017). The N$\mathrm{S}$ trending structure, identified as fault, is associated with several morpho-tectonic features like linear valleys, slide zones, fault scarps, triangular facets and filled fissures. Paleoseismic evidence has been recorded in the form of sand dykes and other soft sediment deformational features within the late Quaternary sediments adjacent to this fault zone. The radiocarbon dating of the carbonized roots preserved in the dykes has given an age of $800 \mathrm{yr}$ BP. The seismic intensity required for formation of these dykes is inferred to be of the order of VII or more on MSK scale.The question whether these features are related to a near-source local earthquake or to a segmentfilling great earthquake needs to be addressed.
Another related question is whether the Yamuna tear fault is an active seismogenic structure or a passive evolving feature that accommodates the part of the overall regional deformation.

In addition to trench investigations a different set of earthquake proxies have also been evaluated during the reporting period. The growth anomalies exhibited bystalagmites including abrupt tilting or rotation of growth axes and growth termination, from the caves located in the eastern Kumaun Himalaya have proven to be useful (see Fig. 2 for location). The U-Th age data from three specimens help in bracketing the dates of growth anomalies. These were dated at $4273 \pm 410$ years BP (2673-1853 BCE), $2782 \pm 79$ years BP (851-693 BCE), $2498 \pm 117$ years BP (605-371 BCE), $1503 \pm 245$ years BP (262-752 CE), $1346 \pm 101$ years BP (563-765 CE), and 687 \pm 147 years BP (1176-1470 CE) (Rajendran et al., 2016a). The dates may correspond to the timings of major/ great earthquakes in the region and the youngest event (1176-1470 CE) may chronologically correspond with either one of the great medieval earthquakes (10501250 and 1259-1433 CE) evident from trench excavations along the MFT.

\section{Eastern Himalaya}

From the perspective of earthquake generation, the eastern Himalaya had hosted two great earthquakes in the recent historical past, namely the 1897 Shillong (Mw 8.2) and the 1950 Upper Assam (Mw 8.6), the latter the largest event within the intercontinental tectonic regimes. Although, the progress from the eastern Himalaya appears slow compared to other parts of the Himalaya, the ongoing work has brought some interesting results (Fig. 5A). Paleoseismic investigations on a fault scarp $(\sim 10 \mathrm{~m})$ identified in West Bengal (Mishra et al., 2016), including ${ }^{14} \mathrm{C}$ ages of detrital charcoal samples revealedthat active faulting occurred between $1688 \mathrm{BCE}$ and $1152 \mathrm{CE}$. These dates are reported to be consistent with the great medieval earthquake of $1255 \mathrm{CE}$. Complementing this data by recalibrated radiocarbon ages from previous studies (at Harmutty, Nameri, and Marha; Figs. 4A and 5B) in the Eastern Himalaya, Mishra et al. (2016) proposed that the $1255 \mathrm{CE}$ earthquake might have ruptured the Himalayan front over a length of $\sim 800 \mathrm{~km}\left(85.87^{\circ}\right.$ to $93.76^{\circ} \mathrm{E}$ longitudes). However, Pierce and Wesnousky (2016) 
are of the view that none of the above-mentioned sites, "when taken singly or together, provide a basis to conclude that an earthquake in $1255 \mathrm{CE}$ ruptured the $800-\mathrm{km}$-section of the Himalayan Frontal Thrust that extends from Sir Khola, Nepal in the west to Harmutti, India in the east".

The investigations made by Pandey et al. (2018a) between the Manas and Dhanshiri Rivers along the HFT in the NE Himalaya (Fig. 5B) suggest that the general deformation pattern reflects north-dipping thrust faults. The surface expression of active faulting is reported to bemanifested only in the form of discontinuous scarps along the frontal thrust and back facing scarps. And, authorsare of the opinion that the deformation may have taken place largely by thrust sheet translation without any pronounced fault-related folding, unlike that of the central and western Himalayas.

Though offsets attributed to earthquake faultingin the region affected by the 1950 earthquake were earlier documented the question remainedalive whether the 1950 Upper Assam earthquake had indeed ruptured the MFT (Rajendran K. et al., 2017). The trenching excavation near Pasighat on the Brahmaputra floodplains (Fig. 5B), located $\sim 150 \mathrm{~km}$ west of the earthquake source, however, reported surface scarps attributed to the 1950 earthquake with a co-seismic slip of $5.5 \pm 0.7 \mathrm{~m}$ (Rao et al., 2017). In a more recent study of the region by Coudurier-Curveur et al. (2019) posits a dual fault geometry involving two orthogonal thrust planes (along Mishmi Thrust and the Main Frontal Himalayan Thrust - Abor Hills) in the genesis of the 1950 Upper Assam earthquake. They assume very large amounts of co-seismic slip and uplifts on the Mishmi Thrust $(>30$ and $>7 \mathrm{~m}$, respectively), thus ruling out the application of classic paleoseismological techniques. Uplifted and abandoned terraces of elevations between $2.6 \pm 0.1 \mathrm{~m}$ to $7.3 \pm 0.1$ $\mathrm{m}$ and $11.5 \pm 0.1 \mathrm{~m}$ have been reported from Pasighat (Coudurier-Curveur et al., 2019).

Another episode of surface rupture was reported from the trench studies (across a scarp in Himebasti Village) on the eastern bank of the Subansiri River along the MFT (Pandey et al., 2018b). The causative earthquake was believed to have occurredin the age range of 1655 and $1826 \mathrm{CE}$ and may have occurred after $1450-1650 \mathrm{CE}$. The scarp shows $\sim 6.8 \mathrm{~m}$ vertical separation and a dip-slip displacement of $11.2 \mathrm{~m}$. It was further suggested that the scarp was formed by the historically reported1697 CE Sadiya earthquake. Combined with the paleoseismicdata from the Bhutan Himalaya, which indicates a great earthquake in 1713 CE (Le Roux-Mallouf et al., 2016), the reports from the Upper Assam therefore suggest two great earthquakes within a short interval ofsixteen years. A moot question is why such a frequency of great earthquakes (with surface scarps) with expected devastation has not found a mention in the regional historical records. The historical archives from the region indicate earthquakes in 1548, 1596 and a strong one in 1663 (1697?) along with the reports of the 1762 Arakan event, but according to the Imperial Gazetteer of India (Oxford, Clarendon Press, 1908, vol. 6, p. 22): "all previous seismic disturbances were, however, completely eclipsed by the earthquake of June 12, 1897, which was the most severe and disastrous of which there is any record in Assam...".

Deformation attributed to tectonism has also been reported from the North Bengal, deciphered from geomorphic analyses (Fig. 5A). Singh et al. (2016) identified a regional fan surface in North Bengal that has been dissected by E-W trending thrusts. The authors suggest that the morphology of the alluvial fan has been shaped by the climatic fluctuations during the period together with tectonic activity along the two Himalayan thrusts. Geomorphic analysis has also been relied on in the southern part of Shillong Plateau where the Dauki Fault is located to ascertain and quantify the active tectonic component in shaping the landscape as evidenced by preferential tilting of drainage basins towards east (Imsong et al., 2016). Here, the higher rate of uplift in the central segment of Shillong Plateau has been attributed to the activity along the Dapsi Thrust and Dauki Fault (Fig. 5A).

Construction of earthquake time line has also been attempted by identifying various generations of liquefaction features from the earthquake impacted regions. For example, Kumar et al. (2016) report the earthquake-related liquefaction features around the Kopili Fault Zone of the Brahmaputra Plains, NE India (Fig. 5A). The age constraints suggest different generations of paleo-liquefaction: $250 \pm 25 \mathrm{yr} \mathrm{BP}, 400$ $770 \mathrm{yr}$ BP and $900 \pm 50 \mathrm{yr}$ BP.The great $1934 \mathrm{Mw} 8.2$ Bihar-Nepal generated a large zone of ground failure and liquefaction in north Bihar, India (Fig. 6; inset). 

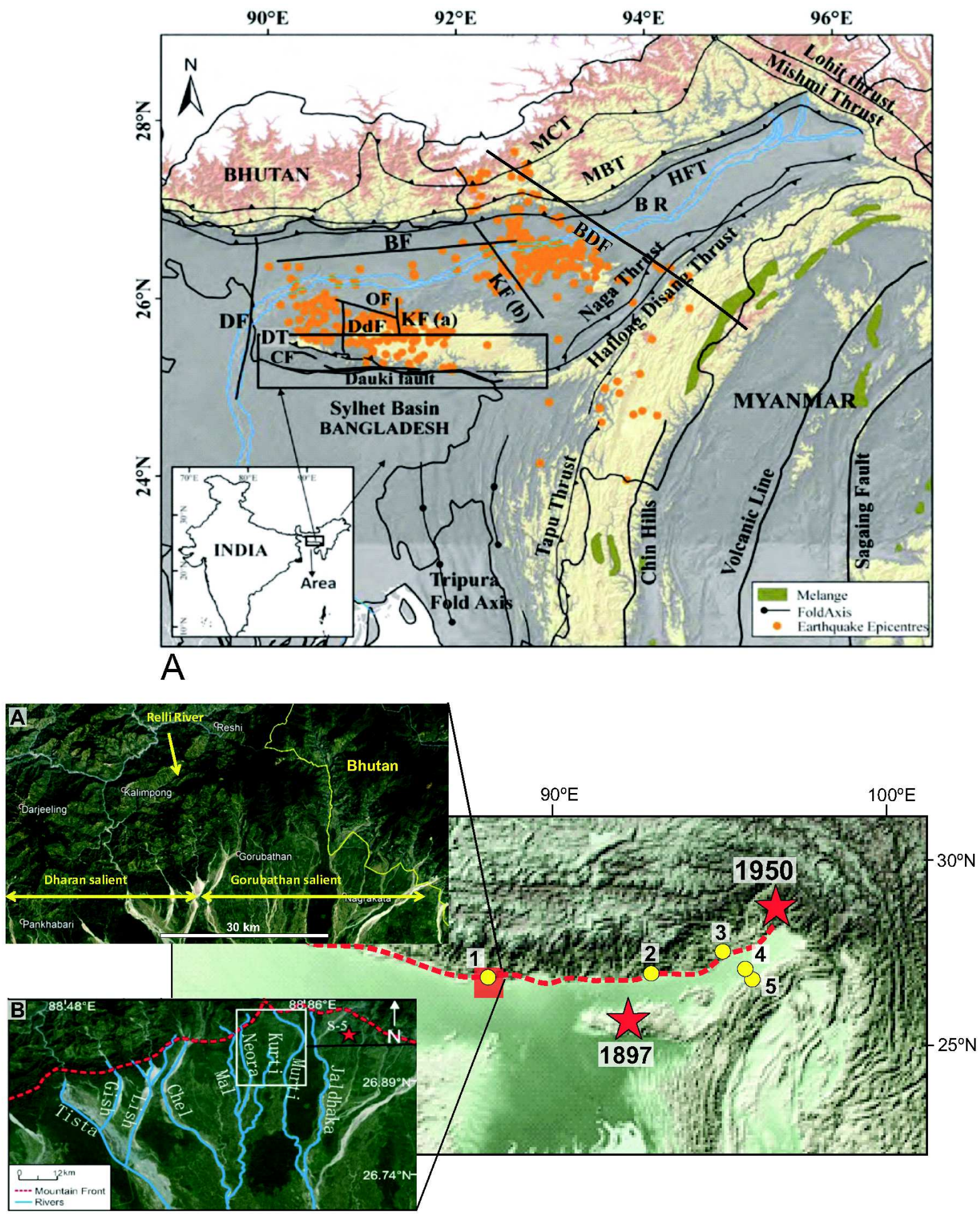

Fig. 5: A. Shaded relief map of the Eastern Himalayan syntaxis along with the Shillong Plateau and theSylhet Basin showing tectonic framework in and around the region (Imsong et al., 2016). Earthquake epicentres USGS of the years 1973-2012. MCT, Main Central Thrust; MBT, Main Boundary Thrust; HFT, Himalayan Frontal Thrust; BF, Brahmaputra Fault; OF, Oldham Fault; DT, Dapsi Thrust; CF, Chokpot Fault; DF, Dhubri Fault; DdF, Dudnoi Fault; KF(a), Kulsi Fault and KF(b), Kopili Fault, BMF: Bomdila Fault. B. The trench sites (1, 2 and 3) of Mishra et al. (2016) along the Eastern Himalayan front and the study sites (4 and 5) of Rao et al. (2017) in the Upper Assam- the epicentral region of the 1950 earthquake (Mw 8.6). Insets A: Map showingDharan and Gorubathan salient; B. The figure shows the study area and the major geomorphic features associated with Gorubathan fault in the north Bengal basin. The sampling sites are marked with red star. Two other E-W scarps, namely, Matiali and Chalsa are also shown (Singh et al., 2016) 
The paleo-liquefaction features from the plains of north Bihar and eastern Uttar Pradesh were dated at 829-971, 886-1090, 907-1181, 1130-1376, 1112-1572, 1492-1672, 1733-1839 and 1814-1854 CE (Rajendran et al., 2016b). One of the liquefaction events dated at 829-971, 886-1090 and 907-1181 CE may correlate with the great earthquake of $\sim 1100 \mathrm{CE}$, recognized in an earlier study from the sections across the frontal thrust in central eastern Nepal. The available data suggest temporally close-spaced earthquakes of both strong and large types that affected the Bihar Plains during the last 1500 years with a combined recurrence interval of $124 \pm 63$ years.

A major challenge in the paleo-liquefaction studies, however, is to constrain the size of the earthquake that caused the liquefaction. Although empirical relations between distance and magnitude is a useful tool in evaluating the minimum energy of an earthquake that induced liquefaction, it may not hold good for all the terrains. Because of the dominant spread of flood plain conditions in the northeast, it is reasonable to assume that even moderate earthquakes may induce spatially well-distributed liquefaction disproportionate to their sizes. A case in point is the 1988 Udaipur earthquake of $\mathrm{Mw}$ 6.7, which had liquefied the floodplains around Dharbanga in Bihar (Fig. 6; inset). A recent example is a magnitude 5.7 earthquake with focal depth of 32 near Ambassa in the state of Tripura on January 5, 2017 that caused liquefaction on the banks of the Manu River in Tripura and along the Dhalai River in the neighboring parts of Bangladesh,

\section{Tectonic and Geomorphic Indicators of Active Deformation Along the Frontal Himalaya}

Neotectonic studies of a deformation front constraints the kinematic evolution and therefore, these studies supplement the paleoseismological work along the frontal Himalaya as they point to: ( $i$ ) deformation associated with slip transfer along the basal Himalayan décollement from the hinterland all the way to the foreland, (ii) great earthquake events, and (iii) critical state of the Himalayan wedge. The Main Frontal thrust (MFT) is typically activated during such events resulting in fault related folding and consequent topographic growth along the frontalthrust. The Himalayan front remains locked during the interseismic periods when the wedge remains subcritical as evident from Global Positioning System geodetic measurements. During the inter-seismic period, the topography generated by frontal deformation is eroded till the next frontal activation. Within this overall framework, neotectonic studies that contribute to the real-time structural geology involving the study of fault related uplift and topography (tectonic landforms) during the Quaternary Period (the most recent 2.6 million years) are reported here.

Srivastava et al. (2016) found evidence of neotectonic activity along the MFT in the west-central Mohand Range in the NW Himalaya (Fig. 3). The fault core is flanked by the hanging wall damage zone characterized by a proximal fault gouge dominated region and a distal damage zone dominated by fractured Middle Siwalik rocks with bands of fault gouge within them. The entire fault zone is capped by uplifted Quaternary gravels suggesting neotectonic uplift along the MFT. Indirect signatures of neotectonic activity are typically obtained from computation of geomorphic indices from basins affected by tectonic activity (Mukul et al., 2017a; b). Srivastava et al. (2017) adopted a new approach to computing geomorphic indices to identify neotectonic deformation in the Relli River basin in the Dharan salient and multiple basins in the Gorubathan recess of the Darjeeling Himalaya (Fig. 5b; inset). These studies have concluded that neotectonic deformation should be studied in conjunction with younger and older deformation signatures to understand their relative roles in the development history of Himalayan wedge. Based on various geomorphic indices, Kaushal et al. (2017) identified spatial variability of tectonic processes across the Nahan salient in the NW Himalaya (Fig. 3). Their results suggest that several thrusts that are present within the Sub-Himalayan part of the salient show evidence of out-of-sequence tectonic activity. These findings are corroborated by the features like tilted terraces and knick-points in the river profiles. The study indicates that the structures to the north of the MFT show major deformation.

Geomorphic characterization of active faults along the frontal Himalaya that can accommodate slip during future earthquakes has been another area of research. Divyadarshini and Singh $(2016,2017)$ discussed about the active structuresaround the Chitwan dun (south of Kathmandu; Fig. 6). They showcased the evidence for the Late Quaternary 


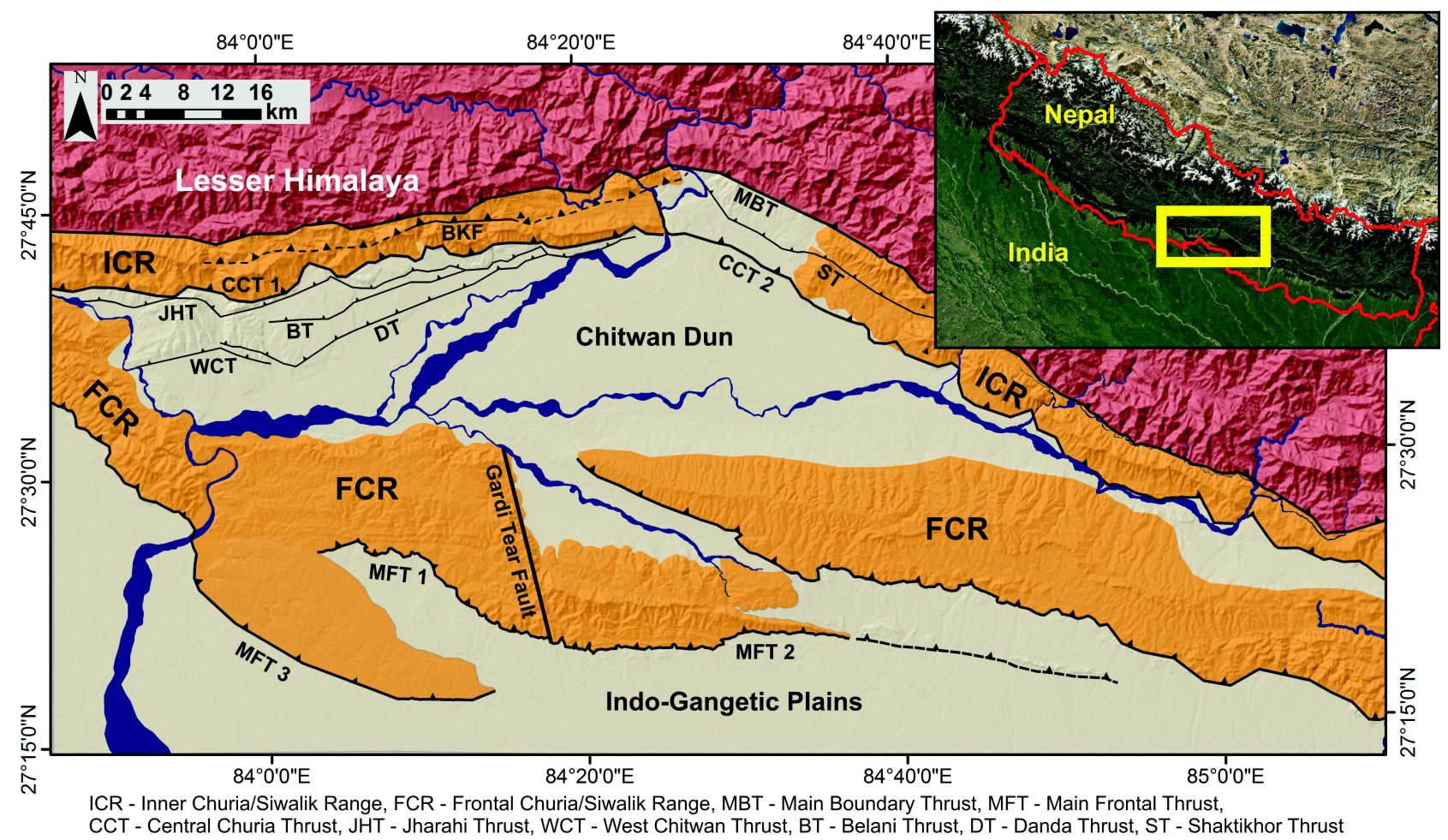

Fig. 6: Map showing the structures identified around Chitwan Dun, central Nepal. The study area lies to the south of the 2015 Gorkha (Mw 7.8) earthquake epicentre. ICR: Inner Churia/Siwalik Range; FCR: Frontal Churia/Siwalik Range; MBT: Main Boundary Thrust; MFT: Main Frontal Thrust; CCT: Central Churia Thrust; JHT: Jharahi Thrust; WCT: West Chitwan Thrust; BT: Belani Thrust; DT: Danda Thrust; ST: Shaktipur Thrust. Inset: Map showing the study area around Chitwan Dun and slump belt generated by the liquefaction associated with the 1934 Bihar-Nepal (Mw 8.2) earthquake. The epicentre of the Mw 6.7, 1988 Udaipur earthquake is also shown

thrust reactivation within the Sub-Himalayan wedge using various geomorphic criteria, namely, presence of knick points, abrupt truncation of fluvial terraces, and abandonment of geomorphic surfaces and deflection of streams. Well-exposed fault zones showing displacement of fractured Siwalik sandstones over the Quaternary gravel deposits and tilted gravel beds in the hanging wall of some structures provided direct evidence for the Quaternary deformation. In another study, Divyadarshini and Singh (2019) explored the structural model and growth history of the Siwalik hills in the Central Himalaya, south of the Chitwan dun (Fig. 6). They identified a pre-existing transverse structurein the region that restricted the length of some MFT segments (Fig. 6); it explains the overlapping of the thrusts - a characteristic growth pattern of frontal faults in the Central Himalaya.

A major geological structure across the Brahmaputra Valley, which stretches from the Eastern Himalayas to the Naga Hills, is the Bomdila fault, whose seismogenic nature is shrouded in mystery. The rivers like the Brahmaputra, Dhansiri, Bargang and many others - are aligned along this structure (Fig. 5A). The influence of the Bomdila structure on the courses of these rivers has been studied by using topographic maps and satellite data and also supplemented by field observations (Sharma and Sharma, 2018).It is concluded that the river systems in the region show morphological anomalies that can only be attributed to the activities associated with the Bomdila fault. The roles of the structures namely, the Kopilli as well as Bomdila faults in the geodynamics of the region are least understood and much needs to be done.

\section{Gujarat}

The Kachchh Basin, located in Gujarat at the western trailing edge of the Indian plate, comprises several east-west trending seismically active faults (Maurya et al., 2017a). The Kachchh Basin evolved firstly by 
rifting and later by post-Deccan Trap inversion stage. During the second stage, the basin was periodically uplifted along the east-west trending master and intrabasinal faults such as: i) the Katrol Hill Fault (KHF), ii) the Kachchh Mainland Fault (KMF), iii) the South Wagad Fault (SWF), iv) the Gedi Fault (GF) and v) the Island Belt Fault (IBF; Fig. 7). Seismic data on the prolonged aftershock sequence of the 2001 Bhuj earthquake (Mw 7.7) shows continuous low-tomoderate seismic activity along multiple faults covering a large area. This area is now commonly known as the Kachchh Seismic Zone. Maurya et al. (2017a) presented data from these active fault zones that cover various aspects of their tectonic geomorphologyand the nature of the faults in the shallow subsurface based on ground-penetrating radar studies. The landscape of the Kachchh region is particularly striking with the presence of raised intertidal regions like the Great Rann, which preserves signatures of coupled effects of both tectonism and climate. For example, Tyagi et al. (2012) opined that between $2.2 \mathrm{ka}$ and $1.4 \mathrm{ka}$ a combination of climate and tectonic activity led to the withdrawal of intertidal environment from the major part of the western Great Rann and earth surface processes are largely modulated by the 1819 Allah Bund earthquake. Subsequently, Padmalal et al. (2019) made an elaborate study of the historical Allah Bund (1819) earthquake zone, which is dominated by the $90 \mathrm{~km}$ long E-W trending south facing scarp in an otherwise flat terrain of the Great Rann of Kachchh. The scarp has been reasonably well described in subsequent historical accounts especially from the western part, where it blocked a distributary of the Indus River.

The area further to the North and West, the Island Belt Fault Zone (IBZ) and Wagad-upland has been investigated by Bhattacharya et al. (2019), and their intention was to ascertain the role of tectonics in landform evolution. The authors document NE-SW and NW-SE trending transverse strike-slip faults that are genetically related to the regional N-S directed compression. Based on the geomorphic configuration, the deformation events have been dated to $\sim 61 / \mathrm{ka}$, 47/ ka, 38/ ka, 29/ ka, 15/ ka and 2/ ka. The extremely low uplift rates $(0.2-0.06 / \mathrm{mm} / \mathrm{yr})$ as compared to the Kachchh mainland $(\sim 1 / \mathrm{mm} / \mathrm{yr})$ is ascribed to the strain partitioning caused due to the presence of the KMF and KHF located south of the IBZ.

\section{Gedi Fault (GF)}

The GF zone is located in the northern part of the Wagad highland region of eastern Kachchh (Fig. 7), where an E-W trending scarp separates the gently folded sandstone and Tertiary rocks. River offset and ground uplift are the most remarkable tectonogeomorphic features in theGFz, where the ground uplift is associated with compressional deformation generated by inter-linking of three fault segments illustrating a left-lateral movement, which has possibly offset the river channels within the GF zone (Kothyari et al., 2016a). The strike slip nature of the Gedi Fault and its near vertical geometry is well-established by seismological and geophysical studies (Kumar et al., 2017).

\section{South Wagad Fault (SWF)}

The SWF zone (see Fig. 7) is located in the southern fringe of Wagad highland and is broken into the several wedge blocks bounded by converging and diverging faults. The geomorphic expression of SWF is a steep southward dipping E-W trending scarp in MesozoicTertiary rocks. The geomorphic signature of SWF is characterized by tectonically governed landforms like, strath terraces along river valleys, truncation of alluvial fans, offset and incision in rivers (Maurya et al., 2017b). Based on geomorphology and seismicity analysis, Kothyari et al. (2016) described SWF as complex wrench geometry of an anastomosing enéchelon fault Based on the fluvial deformation and incision of fluvial sediments two major phases of tectonic movements along the SWF have been identified between 12 and $1 \mathrm{ka}$. Based on the optical chronology the long-term average rate for the SWF was computed as $2.8 \pm 0.1 \mathrm{~mm} / \mathrm{yr}$. Further, based on trench investigation along SWF zone. Three paleoearthquakes have been suggested between 5080 and 1204 BCE.

\section{Kachchh Mainland Fault (KMF)}

The KMF zone is an E-W trending $\sim 170 \mathrm{~km}$ long fault (Fig. 7), which is dissected by several NE-SW, NNE-SSW and N-S oriented transverse faults (Prizomwala et al., 2016). The Quaternary sediments are found in the north flowing river valleys, which cut across the KMF. Based on the geomorphic parameters of active tectonics and seismicity, it is believed that the central and eastern segments of the KMF are 
more active compared to the western segment. The strath terrace sequence at Lothia River on the hanging wall block of KMF suggests tectonic control over its development and it is attributed to two major tectonic events during the Holoceneand one during the Late Pleistocene (>14 ka) (Prizomwala et al., 2016). Based on OSL chronology of strath terraces a minimum long-term average uplift rate of $1.0 \mathrm{~mm} / \mathrm{yr}$ for the eastern segment of KMF is estimated by Prizomwala et al. (2016). Similarly, Maurya et al. (2017a) reported OSL chronology of valley fill and channel fill sequences of various north flowing rivers that cut across the KMF. Their datasets suggest a minimum long-term average uplift rate of $0.8 \mathrm{~mm} / \mathrm{yr}$ similar for Kaila River.

\section{Katrol Hill Fault (KHF)}

The KHF zone is a $75-\mathrm{km}$-long E-W trending south dipping low angle reverse fault (Fig. 7), marked by contact between the Jurassic (Jumara) Formation to the south and the Cretaceous (Bhuj) Formation to the north. Active tectonic nature of the KHF has been reported based on palaeoseismological studies, with a minimum average slip rate of $0.23 \mathrm{~mm} / \mathrm{yr}$ during last $30 \mathrm{ka}$ period and last tectonic event around $3 \mathrm{ka}$. Recent studies using strath terrace sequences along Rukmawati River, which cut across the KHF, suggest a minimum long-term average uplift rate of $0.8 \mathrm{~mm} /$ yr (Das et al., 2016).

\section{Gujarat Coast}

Geological evidence for a paleo-tsunami has been reported from the Saurashtra Coast, Gujarat (Fig. 7; inset) This tsunami event deduced from the preserved sand sheet is dated at $1008 \mathrm{CE}$ (Prizomwala et al., 2018). The sedimentological and geochemical analyses of the sand sheet point to an offshore origin, potentially transported by a high energy wave and deposited in a supratidal environment. The authors suggest its source being a tsunami wave originated from the Makran region in the north Arabian Sea although they do not discount the role of a very large storm as its depositional agent.

\section{Southern and Central Peninsular Shield}

New evidence is emerging on the reactivation of faults associated with shear zones in the peninsular region of southern India (Fig. 8). Identification of features related to active tectonic deformation and paleoseismic manifestations is extremely challenging in the metapmorphic rocks with minimal cover of the Quaternary sediments (John et al., 2016a; John, 2018). The peninsular India is riddled with welldocumented shear zones, which might exhibit reactivation at different locations (Fig. 8A, B and C). The region around Wadakkancheri, Thrissur District in Kerala, which is known for micro-seismic activity since 1989 has been investigated for evidence of active faulting (Fig. 8). The study by Singh et al. (2016) suggests that thefaults located on northwestern continuity near Wadakkanchery is part of the NWSE trending Periyar lineament and these NW-SE trending faults seem to be controlling the courses of smaller rivers in the area. The trenches were excavated near these channels where sand dikes have been identified in the form of dykes (John, 2016b; Fig. 8A). Faulting and associated gouge zones recorded nearAchankovil and Thenmala shear zones are indicative of neotectonics reactivation (Figs. 8A and B).

Some studies have also been reported from the southeastern part of the Indian peninsula. Resmi et al. (2017) also carried out geomorphologic study using morphometric indices analyses and OSL dating across the Palar River basin (Fig. 8). They combined the various morphometric indices to yield the index of relative active tectonics (Iat) in a GIS environment. Based on 'Iat' values, the Palar River basin area was classified into three classes i.e. class 2 with high relative tectonic activity (41\%), class 3 with moderate tectonic activity (47\%) and class 4 with low tectonic activity $(12 \%)$. It is found that none of the sub-basins of the Palar River fall in the class 1, i.e. very high tectonic activity. They used OSL dates to estimate the incision rates, which vary from 0.04 to $6.6 \mathrm{~mm} / \mathrm{yr}$, indicating differential rates of incision and uplift across the basin.

The region around Narmada rift in the central India is associated with occasional moderate earthquakes. The geomorphic studies from the region suggest that large or even great earthquakes may have also occurred in the geological past (Copley et al., 2014). A case in point is the ENE-WSW trending Gavilgarh Fault Zone (GFZ) on the south of the Narmada River that marks the southern margin of the Satpura Mountains within the Central Indian shield 


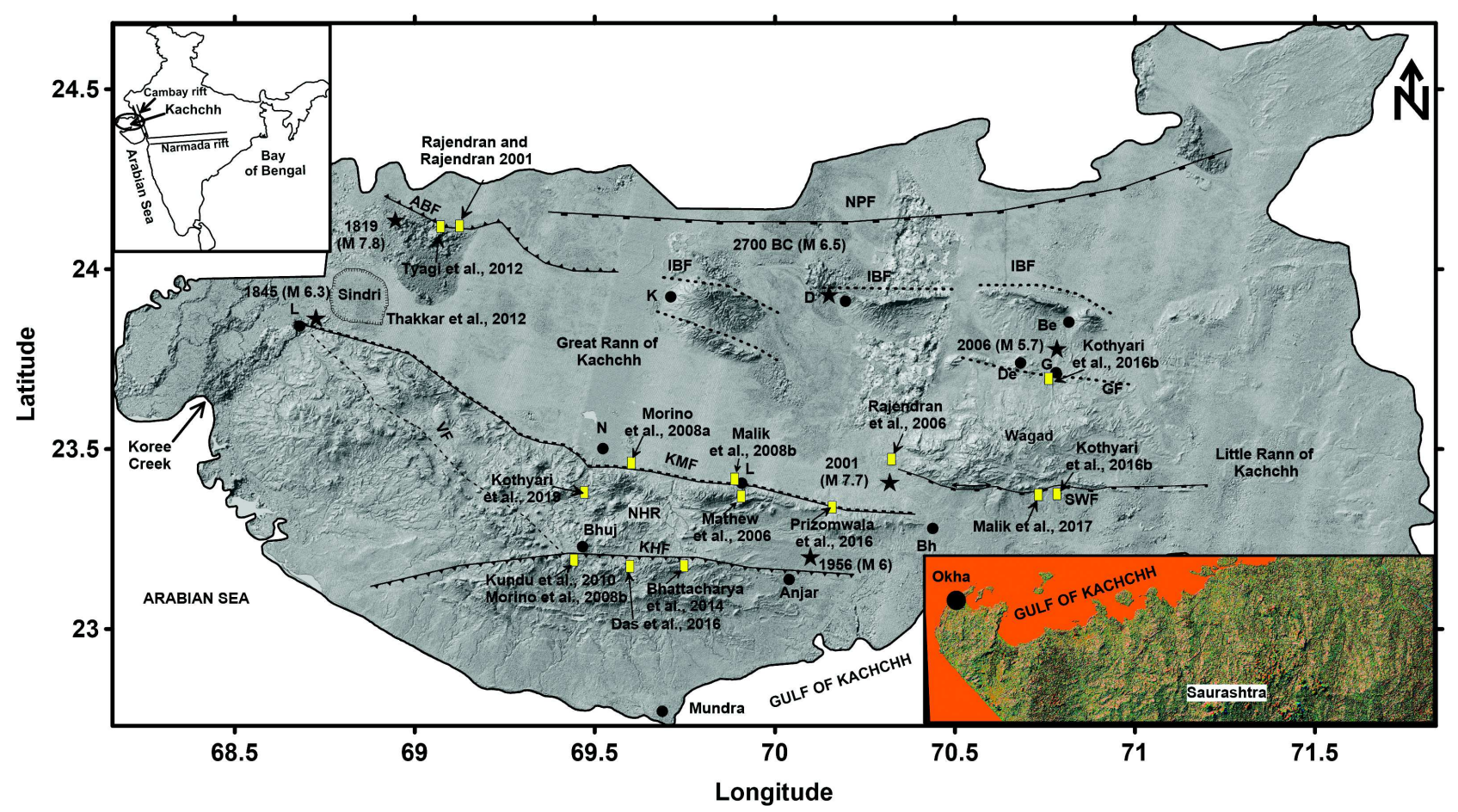

Fig. 7: Map showing the major faults in Kachchh region, Gujarat and the locations of study sites discussed in the text. Locations: Be (Bela), Bh (Bhachau), D (Dholavera), De (Desalpar), G (Gedi), K (Khavada), N (Nirona), L (Lakhpat), L (Lodai); Faults: KHF (Katroll Hill Fault), KMF (Kachchh Mainland Fault), SWF (South Wagad Fault), GF (Gedi Fault), IBF (Island Belt Fault), VF (Vigodi Fault), ABF (Allah Bund Fault), and NPF (Nagar Parkar Fault). Major earthquakes are highlighted by black stars. Inset (bottom): Location of the sand sheet identified as tsunami (Prizomwala et al., 2018)

(Bhattacharjee et al., 2016; Fig. 8). Geomorphological mapping and morphometric analyses of rivers across the GFZ suggest accumulated uplift of the northern side. Luminescence dating of sediment from river terraces indicate multiple faulting events in GFZ at ca. 65-80 ka, ca. $50 \mathrm{ka}, \mathrm{ca} .30-40 \mathrm{ka}$, and ca. $14 \mathrm{ka}$. Interestingly, similar active structures have been reported from the neighboring areas as well.Uplifted terraces and incised valleys associated with Tapti fault have been reported by Copley et al. (2014), located to the west of the GFZ (Fig. 8). It is not clear if these closely situated structural features arepart of a spatially extended single active fault zone. The authors of both papers aver that these structures pose significant seismic hazard.

\section{Andaman and Nicobar Islands}

The Andaman and Nicobar Islands are located to the east of mainland India in the offshore as part of the mega-subduction zone (Figs. 1 and 9). It has been the focus of numerous investigations since the 2004 earthquake that caused large scale damage and huge loss of life and property. A recent study of historical archives available from south India reveals that the penultimate tsunami analogous to the 2004 event occurred in $1343 \mathrm{CE}$ (Rajendran, 2019), which agrees with the age constraints of tsunami sand sheet recovered from the region. While it is important to focus on the tsunami-genic earthquakes along the subduction front, the recent studies also bring out the possibility of large earthquakes like the one occurred in 1941 ( $\geq$ Mw 7.5) under the accretionary prism that may not have generated notable tsunamis like the 1881 event off the Nicobar Island (Okal, 2019; Fig. 9).

In a recent study from South Andaman (Fig. 1), Malik et al. (2019) have reported six paleo-tsunamis prior to the 2004 tsunami. Among these, younger tsunami depositions are linked to the historically reported earthquakes of 1881 (Mw 7.9; Car Nicobar), 1762 (Mw $\leq 8.5$; Arakan Coast, Myanmar) and 1679 (magnitude unknown; north Andaman; Iyengar et al., 1999). The older ones reported have occurred between 1300-1400 CE, 2000-3000 BCE, 2810-3200 $\mathrm{BCE} / 2892-1895 \mathrm{BCE}$ and the oldest one is dated to 


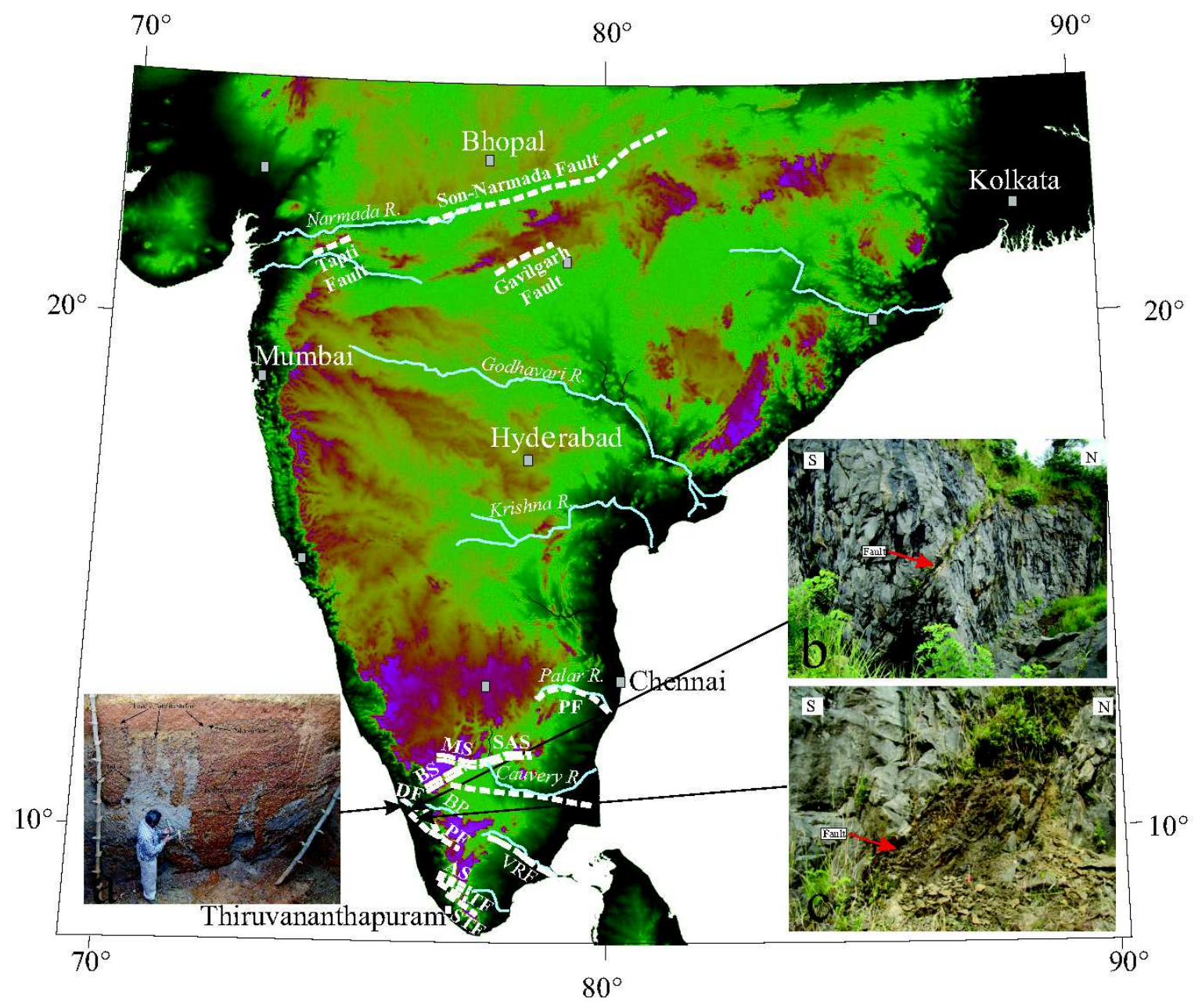

Fig. 8: Map showing major fault zones and shear zones in the central and southern parts of the peninsular shield of India. TF: Tapti fault; GVF: Gavilgarh fault; PF: Periyar fault; DF: Desamangalam fault; TF: Thenmala fault; STF: South Thenmala fault; VRF: Vaigai River Fault; IL: Idamalayar lineament. The study area is shown in rectangle. b and c: Views of two geologically young (brittle) faults observed in Erumapetti $\left(10^{\circ} 40^{\prime} 39.15^{\prime \prime} \mathrm{N}\right.$ : $7^{\circ} 9^{\prime} 13.07^{\prime \prime}$ ) and Mannuthi $\left(10^{\circ} 31 ' 39.13\right.$ "N: $\left.7^{\circ} 16^{\prime} 38.74 " E\right)$. a. Western wall of the $4 \mathrm{~m}$ deep well, near Edappal $\left(10^{\circ} 47^{\prime} 29.41^{\prime \prime} \mathrm{N} 76^{\circ} 2^{\prime} 25.40^{\prime \prime E}\right)$, near Wadkkancherry showing sand injections within the weathered sediment. b. Part of NW-SE trending brittle fault exposed identified near Erumapetti $\left(10^{\circ} 40^{\prime} 39.15^{\prime \prime} \mathrm{N}\right.$ : $\left.76^{\circ} 9^{\prime} 13.07 " \mathrm{E}\right)$ showing closely spaced fractures developed. The fault is exposed $100 \mathrm{~m}$ along the strike with a gouge zone (Singh et al., 2016). c. View of the NW-SE trending south dipping fault observed near Mannuthi $\left(10^{\circ} 31^{\prime} 39.13^{\prime \prime} \mathrm{N}: 7^{\circ} 16^{\prime} 38.74 " E.\right)$; note the vegetation grown along the fault core having thick gouge zone. (Singh et al., 2016)

be pre-5600 BCE. The study site is located at Badabalu (92॰40'29”'E; $11^{\circ} 30^{\prime} 46$ 'N), near Chidiyatapu, South Andaman (Fig. 1 and 9). The authors, later in the text, however, indicate that the 1679 event is nontsunamigenic that is correlated with a stratigraphic unit of 10-20-cm thick peaty soil, attributed to land subsidence (comparable to the land level changes occurred during the $2004 \mathrm{Mw} 9.2$ earthquake rather than the 1941 non-tsunamigenic earthquake). This event is bracketed by a lower and upper bound radiocarbon dates of 1463-1581 CE and 1747-1850
CE. Interestingly, the historical reports of the 1679 earthquake have emanated from Tannassaree and Pegu (17 20'N 96²9'E) seaports of the Irrawaddy delta region, closer to southern Myanmar and north Andaman and the MM intensity at Madras (Chennai) on the east coast of India due to that earthquake did not exceed IV (Iyengar et al., 1999). The two much younger tsunamis, namely the 1881 (1838-1883 CE) and 1762 (1747-1850 CE) were dated based on Optically Simulated Luminescence (OSL) measurements on the samples of the contemporary 


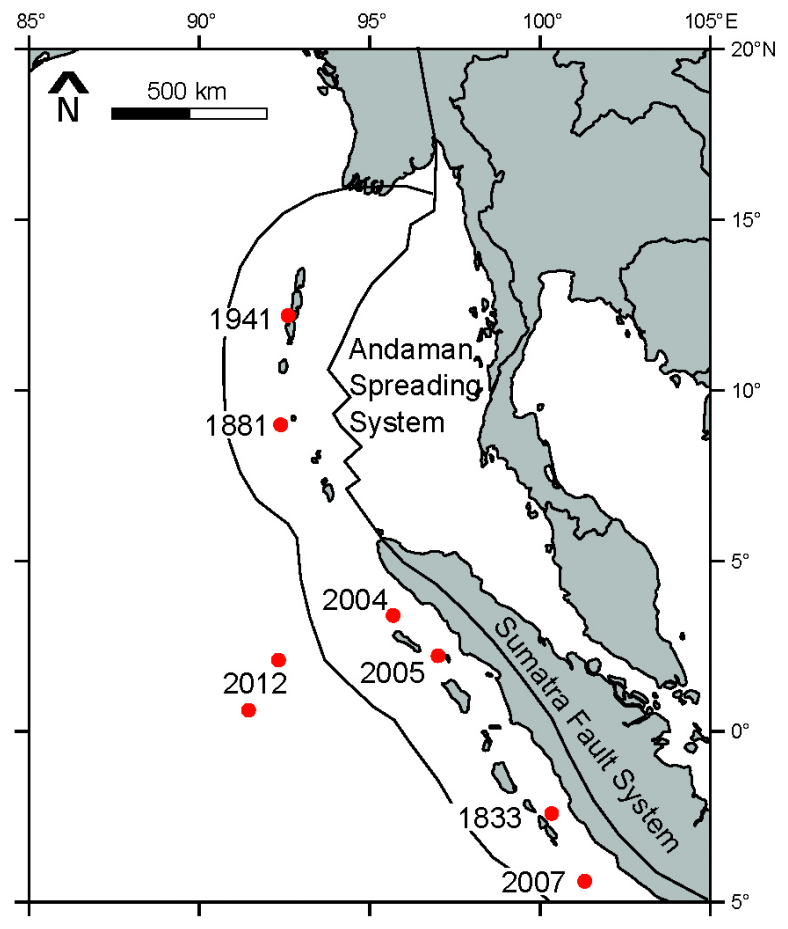

Fig. 9: The Andaman-Sumatra subduction zone showing major earthquakes and structural features in the region including the 1941 earthquake (after Okal (2019)

tsunami deposits, each of them characterized as 10$15 \mathrm{~cm}$ of coarse to medium sand with a few broken shells and coral clasts. As for the 1762 earthquake off the Arakan Coast of Myanmar, the question whether it generated any major distant tsunami inundation remains a puzzle (Rajendran, 2019). The OSL dates of the events, the authors caution that "incomplete resetting of the luminescence signals leads to over-estimation of sediment ages". The dose rate inhomogeneity due to lack of sediment cover over the event layer (e.g. the section showing the1881 tsunami sand) also must be taken into consideration while evaluating the OSL dates of the reported younger events.

Surface expressions of fault activities presumably from the displacement possibly within the accretionary prism have also been reported from the Andaman region (Fig. 9). It is reported that some parts of the south Andaman have revealed traces of compressional tectonics (blind thrusting) and shallowsurface tectonic signatures (Bhat et al., 2018; 2019). It is reported that trench exposures reveal a very low angle thrust cutting across the bedrock surface offsetting the young alluvial surfaces in the Carbyn area of the South Andaman. The mechanisms of earthquakes like the 1941, which appears to be different from the megathrust earthquakes (e.g. the 2004 Indian Ocean earthquake) and their role in activating the accretionary prism needs to be explored further.

\section{Future Directions}

The Quaternary Period for the Indian subcontinent (India, Pakistan, Nepal, Bhutan and Bangladesh) represents an active interval that has shaped the landforms of the region) and preserves the clues that can provide insights into tectonic processes that are of immediate consequence to the human society (see Valdiya and Sanwal, 2017). The paleoseismological methods facilitate unearthing the geological evidence left by the past earthquakes and provide a 'deeper time perspective' on earthquake generation in a variety of tectonic environments. Viewing such results in the context of shorter seismological and satellitebased measurements of crustal movements help us understand not only the distribution of paleoearthquakes in space and time but also many aspects of neotectonics and regional crustal deformation (Forman and Stinchcomb, 2015). The last few years have seen a consistent diversification in paleoseismic investigation and active fault research in India. The studies addressed fault segmentation, earthquake frequency cycles, and inferring theearthquake magnitudes especially along the Himalayan front. As an allied field, the deepened awareness of the tsunami hazard since the 2004 Indian Ocean event led to the emergence of tsunami geology.

Interestingly, the paleoseismological investigations have also been driven by an everincreasing input from associated fields and experts from seismology, geodesy, modeling etc. Although, these interactions have been put to several challenges, especially from the angle of bringing together different data formats with variable spatial and temporal scales and the results appear encouraging. A major point of consensus as far as the Himalayan arc is concerned is the confirmation on the absence of great earthquake/s in the central Himalaya, for several hundreds of years. and a seismic gap in temporal as well as spatial sense is real. And, if the past is the key, the long-elapsed time (600-700 years) implying 
enormous stacking up of strain in the region portends at least one $M \geq 8.5$ earthquake in one of the overlapping segments of the central Himalaya, anytime in future.

However, while appreciating the broad agreements one must also accept gaps and disagreements on how things operated at different spatial and temporal scale. As for the Himalaya studies, the paleoseismic excavation records are likely to miss the blind fault stands. Such questions assume greater importance in the context of the 1934 BiharNepal as the debate on whether this has activated a blind thrust or it had indeed ruptured the surface (Wesnousky et al., 2018; Rizza et al., 2019). Another example is the controversy regarding the location of the fault on the northern side of the Shillong Plateau, which has been variously called as the 'Oldham' fault and the 'Brahmaputra' fault - the former is placed on the northern topographic edge of the plateau and the latter along the Brahmaputra River (Fig. 5A). The recent paper on the crustal structure derived from $\mathrm{P}$ wave receiver function analysis by Mitra et al. (2018) implies faulting beneath the Brahmaputra rather than along the topographic front. For blind thrust scenarios trenching may not provide much information on fault geometry, and therefore, high resolution seismic data may be highly useful in imaging the geometry of the faulted strata (Almeida et al., 2018).

With all the admirable progress listed above the research has come under criticism at different levels considering the methodology, techniques, and of course the interpretations, which could be highly subjective and biased. This needs to be resolved and addressed sooner than later to safeguard the integrity of science and its application. Validating evidence should also be accrued from allied methods, and therefore it is important to initiate systematic geophysical surveys

\section{References}

Alam A, Sultan Bhat, M Kotlia, B S Ahmad B, Ahmad S, Taloor A K and Ahmad H F (2017) Coexistent pre-existing extensional and subsequent compressional tectonic deformation in the Kashmir basin, NW Himalaya Quaternary International 444 201-208

Almeida R V, Hubbard J, Liberty L, Foster A and Sapkota S N (2018) Seismic imaging of the Main Frontal Thrust in (e.g. seismic, thermal, electrical, magnetic and gravitational) to complement the paleoseismological studies. Shallow and deep reflection techniques should be employed in critical areas to understand the nature and style of faulting. Thus, the future work should focus on evolving new strategies and methodologies to integrate different datasets in a coherent manner to yield practically relevant results.

An aspect that will also become important in the years to come is how the varied and site-specific paleoseismological results can be integrated to develop an inventory of active faults for the whole country. From research point of view attention may also be given to the observational and theoretical elements of tectonic geomorphology and use them as tools to constrain paleo-earthquake activity. The application of aerial photography and remote sensing (e.g. LIDAR and InSAR techniques) at many scales and radiation bands will have to become a part of this endeavor. These efforts will also help in augmenting the measurement precision of various parameters related to morphology and landscape evolution dynamics. The paleoseismological and active fault research has now found its place in public programs where the research updates are being shared through news articles and popular journals, which raise awareness in both society and administrative circles for better hazard preparedness.

\section{Acknowledgments}

We thank Professors Arvind K Jain, Dhiraj M Banerjee, Somnath Dasgupta, Sunil Bajpai and V C Thakur for their interest and invitation to prepare this article. We are grateful to Dr. Devender Kumar for a thorough review, and for the thoughtful comments that vastly improved the manuscript. Dr. Jaishri Sanwal helped in drafting the figures. Dr. Ananya Divyadarshini assisted in final editorial work.

Nepal reveals a shallow décollement and blind thrusting Earth and Planetary Science Letters 494 216-225

Ahmad S, Bhat M L, Bhat M S, Alam A, Ahmad B, Rasool A, Ahmad H F, Ali U and Afzal A (2017) Geomorphic indicators of Balapur fault in Kashmir Basin and kinematic analysis with respect to NW Himalaya Jour Himalayan Ecol Sustain Dev 12 72-77

Arora S, Malik J N and Sahoo S (2019) Paleoseismic evidence of 
a major earthquake event(s) along the hinterland faults: Pinjore Garden Fault (PGF) and Jhajra Fault (JF) in northwest Himalaya, India Tectonophysics 757 DOI: 10.1016/j.tecto.2019.01.001

Bai L, Klemperer S L, Mori J, Karplus M S, Ding L, Liu H, Li G, Song B and Dhakal S (2019) Lateral variation of the Main Himalayan Thrust controls the rupture length of the 2015 Gorkha earthquake in Nepal Sci Advances 5 eaav0723

Bhattacharjee D, Jain V, Chattopadhyay A, Biswas R H and SinghviA K (2016) Geomorphic evidences and chronology of multiple neotectonic events in a cratonic area: Results from the Gavilgarh Fault Zone, central India Tectonophysics 677 199-217

Bhattacharya F, Rastogi B K, Ngangom M, Thakkar M G and Patel R C (2013) Late Quaternary climate and seismicity in the Katrol hill range, Kachch,, western India Jour Asian Ear Sci 73 114-120

Bhattacharya F, Rastogi B K, Thakkar M G, Patel R C and Juyal N (2014) Fluvial landforms and their implication towards understanding the past climate and seismicity in the northern Katrol Hill Range, western India Quaternary International 333 49-61

Bhattacharya F, Chauhan G, Prasad A D, Patel R C and Thakkar M G (2019) Strike-slip faults in an intraplate setting and their significance for landform evolution in the Kachchh peninsula, Western India Geomorphology 328 118-137

Bhat G R, Balaji S, Bali B S, Iqbal V, Balakrishna B and Hussain H (2018) Paleoseismological investigations along Joggers Park Fault, Port Blair, South Andaman: Implications towards delineation of blind thrusting and related crustal deformation through ground penetrating radar (GPR) and electrical resistivity techniques (ERT and VES) Jour Geol Soc India 91 81-90

Bhat G R, Balaji S, Iqbal V, Balakrishna B and Yousuf M (2019) Neotectonics and related crustal deformation along Carbyn thrust fault, South Andaman, India: implications of the frontal surface faulting and propagation of tectonic activity towards Andaman trench Arab JourGeosci 2149 doi: 10.1007/s12517-019-4282-7

Bilham R (2019) Himalayan earthquakes: a review of historical seismicity and early 21 st century slip potential Geol Soc London Special Publications $\mathbf{4 8 3}$ https://doi.org/10.1144/ SP483.16

Copley A, Mitra S, Sloan R A, Gaonkar S and Reynolds K (2014)Active faulting in apparently stable peninsular India: Riftinversion and a Holocene-age great earthquake on the Tapti Fault Jour Geophys Res 119 doi: 10.1002/ 2014JB011294
Coudurier-Curveur A, Tapponnier P, Okal E, Vander Woerd J, Kali E, Choudhury S, Baruah S, Etchebes M and Karakas Ç (2019) A composite rupture model for the great 1950 Assam earthquake across the cusp of the East Himalaya syntaxis Earth and Planet Sci Lett http://doi.org/10.1016/ j.eps1.2019.115928

Das A, Chauhan G, Prizomwala S P, Thakkar M G and Rastogi B K (2016) Tectonic variability along the South Katrol Hill Fault, Kachchh, Western India: Insights from geomorphic indices Zeitschriftfür Geomorphologie 60 209-218 doi: 10.1127/zfg/2016/0201

Dey S, Thiede R C, Schildgen T F, Wittmann H, Bookhagen B, Scherler D and Strecker M R (2016) Holocene internal shortening within the northwest Sub Himalaya: Out of sequence faulting of the Jwalamukhi Thrust, India Tectonics 35 2677-2697 doi: 10.1002/2015TC004002

Divyadarshini A and Singh V (2016) Seismic Threat to the Chitwan and Hetauda Duns, Central Nepal Cur Sci 111 1309-1310

Divyadarshini A and Singh V (2017) Identifying active structures in the Chitwan Dun, Central Nepal, using longitudinal river profiles and SL index analysis Quaternary International 462 176-193

Divyadarshini A and Singh V (2019) Investigating Topographic Metrics to Decipher Structural Model and Morphotectonic Evolution of the Frontal Siwalik Ranges, Central Himalaya, Nepal Geomorphology 337 31-52

Dubey R K, Dar J A and Kothyari G C (2017) Evaluation of relative tectonic perturbations of the Kashmir Basin, Northwest Himalaya, India: An integrated morphological approach Jour Asian Ear Sci 148 153-172

Forman S L and Stinchcomb G E (2015) Views on grand research challenges for Quaternary geology, geomorphology and environment Frontiers in Earth Science 347 doi: 10.3389/ feart.2015.00047

Hubbard J, Almeida R, Foster A, Sapkota S, Bürgi P and Tapponnier P (2016) Structural segmentation controlled the $2015 \mathrm{Mw} 7.8$ Gorkha earthquake rupture in Nepal Geology 44 639-642

Imsong W, Choudhury S and Phukan S (2016) Ascertaining the neotectonic activities in the southern part of Shillong Plateau through geomorphic parameters and remote sensing data Cur Sci 110 91-98

Iyengar R N, Sharma D and Siddiqui J M (1999) Earthquake history of Indian medieval times, India Indian Jour Hist Sci 34 181-237

Jayangondaperumal R, Kumahara Y, Thakur V C, Kumar A, Srivastava P, Dubey S, Joevivek V and Dubey A K (2017a) Great earthquake surface ruptures along backthrust of the 
Janauri anticline, NW Himalaya Jour Asian Ear Sci 133 89-101

Jayangondaperumal R, Daniels R M, Niemi T M (2017b) A paleoseismic age model for large-magnitude earthquakes on fault segments of the Himalayan Frontal Thrust in the Central Seismic Gap of northern India Quaternary International 462 130-137

John B, Singh Y and Praseeda E (2016a) Neotectonic evidences associated with shear zones of south India in A. P. Pradeepkumar, and E.Shaji (eds): Shear Zones and Crustal Blocks of Southern India, Proc UGCSAPDRS II \& CTESS seminar 3 2-9

John B, Babu A R, Subrahmanyam D S, Singh Y, Divyalakshmi K S, Praseeda E, Samui P and Ganapathy G P, (2016b) Seismicity of Kerala: An update, RARE 2016, Atlantis Press 217-220

John B (2018) Importance of Geological Studies in Earthquake Hazard Assessment. In Integrating Disaster Science and Management: Global Case Studies in Mitigation and Recovery Elsevier Book Chapter 2 27-40

Joshi D D, Kandpal G C and John B (2017) Active fault study in the Yamuna Tear Zone, GSI Spl Publication No. 110. 40

Kaushal R K, Singh V, Mukul M, Jain V (2017) Identification of deformation variability and active structures using geomorphic markers in the Nahan salient, NW Himalaya, India Quaternary International 462 194-210

Kothyari G C and Luirei K (2016) Late Quaternary tectonic landforms and fluvial aggradation in the Saryu River valley: Central Kumaun Himalaya Geomorphology 268 159-176

Kothyari G C, RastogiB K, Morthekai P and Dumka R K, (2016a) Landform development in a zone of Active Gedi Fault Eastern Kachchh Rift Basin, Western India Tectonophysics 670 115-126

Kothyari G C, Rastogi B K, Morthekai P, Dumka R K and Kandregula R S (2016b) Active segmentation assessment of the tectonically active South Wagad Fault in Kachchh, Western Peninsular India Geomorphology 253 491-507

Kothyari G C, Dumka R K, Singh A P, Thakkar M G and Biswas S K (2016c) Tectonic evolution and stress pattern of South Wagad Fault at the Kachchh Rift Basin in western India Geological Magazine 154 875-887 doi: 10.1017/ S0016756816000509

Kothyari G C, Kandregula R S and Luirei K (2017a) Morphotectonic records of neotectonic activity in the vicinity of North Almora Thrust Zone, Central Kumaun Himalaya Geomorphology 285 272-286

Kothyari G G, Shukla A D and Juyal N (2017b) Reconstruction of Late Quaternary climate and seismicity using fluvial landforms in Pindar River valley, Central Himalaya, Uttarakhand, India QuatInternat 443 248-264

Kothyari G C, Joshi N, Taloor A K, Kandregula R S, Kotlia B S, Pant C C, and Singh R K (2019a) Landscape evolution and deduction of surface deformation in the Soan Dun, NW Himalaya, India QuatInternat 507 302-323

Kothyari G C, Shirvalkar P, Kandregula R S, Rawat Y, Dumka R $\mathrm{K}$ and Joshi N (2019b) Holocene tectonic activity along Kachchh Mainland Fault: Impact on late mature Harappan civilization, Kachchh, western India Quaternary International $\mathbf{5 0 7}$ 274-287

Kumahara Y and Jayangondaperumal R (2013) Paleoseismic evidence of a surface rupture along the northwestern Himalayan Frontal Thrust (HFT) Geomorphology 180 47-56 DOI: 10.1016/j.geomorph.2012.09.004

Kumar D, Reddy D V and Pandey A K (2016) Paleoseismic investigations in the Kopili Fault Zone of North East India: Evidences from liquefaction chronology Tectonophysics $67465-75$

Kumar G P, Mahesh P, Nagar M, Mahender E, Kumar V, Mohan K and Ravi Kumar M (2017) Role of deep crustal fluids in the genesis of intraplate earthquakes in the Kachchh region, northwestern, India Geophys Res Lett 44 4054-4063 DOI: 10.1002/2017GL072936

Le Roux-Mallouf R, Ferry M, Ritz J F, Berthet T, Cattin R and Drukpa D (2016) First paleoseismic evidence for great surface-rupturing earthquakes in the Bhutan Himalayas Jour Geophys Res 121 DOI: 10.1002/ 2015JB012733

Malik J N, Nakata T, Philip G, Suresh N and Virdi N S (2008a) Active fault and paleoseismic investigation: Evidence of historic earthquake along Chandigarh fault in the frontal Himalaya zone, NW India Jour Him Geol 29 109-117

Malik J N, Morino M, Mishra P, Bhuiyan C and Kaneko F (2008b) First Active Fault Exposure Identified along Kachchh Mainland Fault: Evidence from Trench Excavation near Lodai Village, Gujarat, Western India Jour Geol Soc India 71 201-208

Malik J N, Naik S P, Santiswarup S and K Okumora (2016) Paleoseismic evidence of the $1505 \mathrm{CE}$ (?) and $1803 \mathrm{CE}$ earthquakes from the foothill zone of the Kumaun Himalaya along the Himalayan frontal thrust (HFT), India Tectonophysics 714 133-145 DOI: 10.1016/j.tecto. 2016.07.026

Malik J N, Gadhavi MS, Kothyari G C and Satuluri S (2017) Paleo-earthquake signatures from the South Wagad Fault (SWF), Wagad Island, Kachchh, Gujarat, Western India: A potential seismic hazard Jour Struct Geol 95 142-159

Malik J N, Johnson, F C, Khan A, Sahoo S, Irshad R, Paul D, 
Arora S, Baghel P K and Chopra S(2019) Tsunami records of the last 8000 years in the Andaman Island, India, from megaand large earthquakes: Insights on recurrence interval Scientific Reports 91-14 doi: 10.1038/s41598-019-547506

Maurya D M, Chowksey V, Patidar A K and Chamyal L S (2017a) A review and new data on neotectonic evolution of active faults in the Kachchh Basin, Western India: legacy of postDeccan Trap tectonic inversion Geol Soc London, Special Publications 445 237-268

Maurya D M, Chowksey V, Tiwari P and Chamyal L S (2017b) Tectonic geomorphology and neotectonic setting of the seismically active South Wagad Fault (SWF), Western India using field and GPR data Acta Geophysics 65 1167-1184

Mitra S, Priestley K F, Borah K and Gaur V K (2018) Crustal Structure and Evolution of the Eastern HimalayanPlate Boundary System, Northeast India Jour Geophys Res 123 621-640DOI: 10.1002/2017JB014714

Mishra R L, Singh I, Pandey A, Rao P S, Sahoo H K and Jayangondaperumal R (2016) Paleoseismic evidence of a giant medieval earthquake in the eastern Himalaya Geophys Res Lett 43 5707-5715

Mugnier J-L, V Vignon, R Jayangondaperumal, R Vassallo, M A Malik, A Replumaz, R P Srivastava, F Jouanne, J F Buoncristiani, H Jomard, J Carcaillet (2017) A complex thrust sequence in western Himalaya: The active Medlicott Wadia Thrust QuatInternat 46 109-123 DOI: 10.1016/ j.quaint 2017.05.028

Mukul M, Srivastava V and Mukul M (2017a) Out-of-sequence reactivation of the Munsiari thrust in the Relli River basin, Darjiling Himalaya, India: Insights from Shuttle Radar Topography Mission digital elevation model-based geomorphic indices Geomorphology 284 229-237

Mukul M, Srivastava V, Jade S and Mukul M (2017b) Uncertainties in the Shuttle Radar Topography Mission (SRTM) Heights: Insights from the Indian Himalaya and Peninsula Scientific Rept 741672 DOI: 10.1038/srep41672

Okal E (2019) The Large Andaman Islands Earthquake of 26 June 1941: Why no significant tsunami? Pure and Applied Geophys 1-18 DOI: 10.1007/s00024-018-2082-8

Ortiz M and Bilham R (2003) Source area and rupture parameters of the 31 December $1881 \mathrm{Mw}=7.9$ Car Nicobar earthquake estimated from tsunami records in the Bay of Bengal Jour Geophys Res 108221 doi: 10.1029/ 2002JB001941

Padmalal A, Khonde N, Maurya D M, Shaikh M, Kumar A, Vanik N and Chamyal L S (2019) Geomorphic characteristics and morphologic dating of the Allah Bund
Fault scarp, Great Rann of Kachchh, Western India In: Tectonics and Structural Geology: Indian Context, Springer 55-74

Pandey A, Singh I, Mishra R L, Rao P S, Srivastava H B and Jayangondaperumal R (2018a). Active tectonics in the Assam seismic gap between the meizoseismal zone of AD 1934 and 1950 earthquakes along eastern Himalayan front, India Jour Earth Sys Sci 12766 doi: 10.1007/s12040-0180967-7

Pandey A, Jayangondaperumal R, Priyanka R S, Singh I, Mishra R L, Srivastava H B and Srivastava P (2018b) The 17th century great earthquake at Hime village, Subansiri River Valley, Eastern Himalayan Front, IndiaConference: 33rd Himalaya-Karakorum-Tibet Workshop, Lausanne, Switzerland DOI: 10.5281/zenodo.1403887

Philip G, Suresh N P and Jayangondaperumal R (2017) Late Pleistocene-Holocene strain release by normal faulting along the Main Boundary Thrust at Logar in the northwestern Kumaon Sub Himalaya, India Quaternary International 462 50-64

Pierce I and Wesnousky S G (2016) On a flawed conclusion that the $1255 \mathrm{AD}$ earthquake ruptured $800 \mathrm{~km}$ of the Himalayan Frontal Thrust east of Kathmandu Geophys Res Lett DOI: 10.1002/2016GL070426

Prizomwala S P, Das A, Chauhan G, Solanki T, Basavaiah N, Bhatt N, Thakkar M G and Rastogi B K (2016) Late Pleistocene-Holocene uplift driven terrace formation and climate-tectonic interplay from a seismically active Intraplate setting: An example from Kachchh, Western India Jour Asian Ear Sci 124 55-67

Prizomwala S P, Gandhi D, Bhatt N, Winkler W, Ravi Kumar M, Makwana N and Bhatt N (2018) Geological evidence for AD 1008 tsunami along the Kachchh coast, Western India: Implications for hazard along the Makran Subduction Zone Scientific Reports 816816

Rajendran C P (2019) Historical accounts of sea-disturbances from south India and their bearing on the penultimate predecessor of the 2004 tsunami Seism Res Lett 90 774783 DOI: $10.1785 / 0220180355$

Rajendran C P, John B, Anandasabari K, Sanwal J, Rajendran K, Kumar P and Chopra S (2018a) On the paleoseismic evidence of the 1803 earthquake rupture (or lack of it) along the frontal thrust of the Kumaun Himalaya Tectonophysics 722C 227-234

Rajendran C P, Sanwal J, John B, Anandasabari K,Rajendran K, Kumar P, Jaiswal M K and Chopra S (2018b) Footprints of an elusive mid-14 ${ }^{\text {th }}$ century earthquake in the central Himalaya: Consilience of evidence from Nepal and India 
Geological Journal 1-18 doi: 10.1002/ gj.3385

Rajendran C P, Sanwal J, Morell K, Sandiford M, Kotlia R S, Hellstrom J and Rajendran K (2016a) Stalagmite growth perturbations from the Kumaun Himalaya as potential earthquake recorders Jour Seismology 20 579-594

Rajendran C P, John B, Rajendran K and Sanwal J (2016b) Liquefaction record of the great 1934 earthquake predecessors from the north Bihar alluvial plains of India Jour Seismology 20 733-745 doi: 10.1007/s10950-0169554-z

Rajendran K, Parameswaran R and Rajendran C P (2017) Seismotectonics perspectives on the Himalayan arc and contiguous areas: Inferences from past and present earthquakes Earth Science Reviews 173 1-30 doi: 10.1016/ j.earscirev. 2017.08.003

Rao S P, Jayangondaperumal R, Pandey A, Mishra R L, Singh I, Bhushan R, Srivastava P, Ramachandran S, Shah C, Kedia S, Sharma A K and Bhat G R (2017) Primary surface rupture of the 1950 Tibet-Assam great earthquake along the eastern Himalayan front, India Scientific reports 7 Article number: 5433

Resmi M R, Achyuthan H and Jaiswal M K (2017) Holocene tectonic uplift using geomorphometric parameters, GIS and OSL dating: Palar River basin, southern peninsular India ZeitschriftfürGeomorphologie 61 243-265

Rizza M, Bollinger L, Sapkota S N, Tapponnier P, Klinger Y, Karakas Ç E, Kali E, Etchebes M, Tiwari D R, Siwakoti I, Bitri A and Bes de Berc S (2019) Post earthquake aggadation processes to hide surface ruptures in thrust systems: The M8.3, 1934, Bihar-Nepal earthquake ruptures at Charnath Khola (Eastern Nepal) Journal of Geophysical Research: Solid Earth 124 9182-9207 https://doi.org/ 10.1029/ 2018JB016376

Sahoo S and Malik J N (2017) Active fault topography along Kangra Valley Fault in the epicentral zone of 1905 Mw7.8 earthquake NW Himalaya, India Quaternary International 462 90-108

Sana H and Nath S K (2016) Liquefaction potential analysis of the Kashmir valley alluvium, NW Himalaya Soil Dynam Earthquake Eng 85 11-18

Sana H, Bhat F A and Sana S (2018) The ancient temples of Kashmir turned from marvel to ruin by earthquakes? A case study of the Pattan twin temples (A.D. 883-902) Seism Res Lett 90 358-365 doi: 10.1785/0220180270

Shah AA and Malik J N (2017) Four major unknown active faults identified, using satellite data, in India and Pakistan portions of NW Himalaya Nat Hazards 88 1845-1865 doi: 10.1007/ s1 1069-017-2949-5
Sharma J N and Sharma S (2018)Neotectonic activity of the Bomdila Fault in northeastern India from geomorphological evidences using remote sensing and GIS Jour Earth Syst Sci 127113 doi: 10.1007/s12040-018 -1008-2

Singh A K, Jaiswal M K, Pattanaik J K and Rawat M (2016) Luminescence Chronology of Alluvial fan in North Bengal, India: Implications to Tectonics and Climate Geochronometria 43 102-112

Singh Y, John B, Ganapathy G P, George A, Harisanth S, Divyalakshmi K S and Kesavan S (2016) Geomorphic observations from south western terminus of Palghat Gap, south India and their tectonic implications Jour Earth Sys Sci 125 821-839 doi: 10.1007/s12040-016-0695-9, 125, 821-839.

Singh T, Awasthi A K and Caputo R (2012) The Sub-Himalayan fold-thrust belt in the 1905-Kangra earthquake zone: A critical taper model perspective for Seismic Hazard Assessment Tectonics 31 doi: 10.1029/2012TC003120.

Srivastava V, Mukul M and Barnes J B (2016) Main Frontal thrust deformation and topographic growth of the Mohand Range, northwest Himalaya Jour Struct Geol 93 131-148

Srivastava V, Mukul M and Mukul M (2017) Quaternary deformation in the Gorubathan recess: Insights on the structural and landscape evolution in the frontal Darjiling Himalaya Quaternary International 462 138-161

Srivastava V, Mukul M, Barnes J B and Mukul M (2018) Geometry and Kinematics of Main Frontal thrust related fault propagation folding in the Mohand Range, northwest Himalaya Jour Struct Geol 115 1-18 DOI: 10.1016/ j.jsg.2018.06.022

Stolle A B, Schwanghart W, Hoelzmann P, Adhikari B R, Fort M and Korup O (2017) Catastrophic valley fills record large Himalayan earthquake, Pokhara, Nepal Quaternary Science Reviews 177 88-103 doi: 10.1016/. quascirev.2017.10.05

Taloor A K, Ray P K, Jasrotia A S, Kotlia B S, Alam A, Kumar S G, Kumar R, Kumar V and Roy S (2017) Active tectonic deformation along reactivated faults in Binta basin in Kumaun Himalaya of north India: Inferences from tectonogeomorphic evaluation Zeitschriftfür Geomorphologie 61 $159-180$

Thakur V C, Joshi M, Sahoo D, Suresh N, Jayangondapermal R and Singh A (2014) Partitioning of convergence in Northwest Sub Himalaya: estimation of late Quaternary uplift and convergence rates across the Kangra reentrant, North India Int Jour Ear Sci (GeolRundsch) 1031037 1056

Thakur V C, Jayangondaperumal R and Joevivek V (2018) Seismotectonics of Central and NW Himalaya: plate 
boundary - wedge thrust earthquakes in thin - and thick skinned tectonic framework, in Crustal Architecture and Evolution of the Himalaya-Karakoram-Tibet Orogen Sharma, R., Villa, I. M. and Kumar, S. (Eds) Geol Soc London 481 41-63 doi: 10.1144/SP481.8

Tyagi A K, Shukla A D, Bhushan R, Thakkar P S, Thakkar M G and Juyal N (2012) Mid-Holocene sedimentation and landscape evolution in the western Great Rann of Kachchh, India Geomorphology 151 89-98

Valdiya K S and Sanwal J (2017) Neotectonism in Indian Subcontinent: Landscape Evolution Elsevier, ISBN: 9780444639714, 436p
Wesnousky S G, Kumahara Y, Chamlagain D, Pierce I K, Reedy T, Angster S and Gin B (2017) Large paleoearthquake timing and displacement near Damak in eastern Nepal on the Himalayan frontal thrust Geophys Res Lett 44 82198226 doi: 10.1002/2017GL074270

Wesnousky S G, Kumahara Y, Nakata T, Chamlagain D and Neupane P (2018) New observations disagree with previous interpretations of surface rupture along the Himalayan Frontal Thrust during the great 1934 BiharNepal earthquake Geophys Res Lett 45 2652-2658 doi: 10.1002/2018GL077035. 